\title{
Burmistrz Słupska Fryderyk Pałubicki i jego wkład w sporządzenie przeróbki atlasowej wersji mapy Pomorza Eilharda Lubinusa
}

\author{
Roch Pałubicki \\ https://orcid.org/0000-0002-9573-1871 \\ Poznań
}

Zarys treści: Celem artykułu jest omówienie okoliczności i czasu powstania znanej siedemnastowiecznej przeróbki mapy Księstwa Pomorskiego, a także jej źródeł kartograficznych i roli, jaką odegrała w kartografii pomorskiej. Do tej pory osoba wskazana na mapie jako Frid. Palbitzke nie była zidentyfikowana. Artykuł omawia jej tożsamość, wkład w opracowanie przeróbki mapy oraz cel jej sporządzenia.

Stowa kluczowe: historia kartografii, kartografia Pomorza Zachodniego, historia Słupska, XVII w., Fryderyk Pałubicki, Pałubiccy

\section{Wprowadzenie}

Na znanej mapie Księstwa Pomorskiego publikowanej w atlasach Hondiusa-Janssoniusa, będącej modyfikacją mapy Lubinusa ${ }^{1}$, widnieje wzmianka: nunc iterum correcta per Frid. Palbitzke Pomer. L.L. Studiosum. Do tej pory nie zauważono, że pod tym określeniem kryje się Fryderyk Pałubicki, żyjący w XVII w. burmistrz Słupska i landrat.

Na temat Pałubickiego jako szlacheckiego patrycjusza Słupska istnieje sporo wzmianek w literaturze, lecz z wyjątkiem prac Zygmunta Szultki niewiele wnoszą i obracają się w kręgu tych samych kilku faktów. Najwartościowszy jest biogram autorstwa Szultki, skupiony jednak na

\footnotetext{
${ }^{1}$ W pracy tej w odniesieniu do analizowanego dzieła kartograficznego używam sformułowania "mapa Pałubickiego" w sensie formalnym (zamiennie z pojęciem „przeróbka”). Nie jest moim zamiarem stwarzanie wrażenia, że chodzi tu o dzieło oryginalne (była to w istocie kompilacja), ani że Fryderyk Pałubicki był kartografem we właściwym rozumieniu. Zakres jego wkładu autorskiego w opracowanie tej kompilacji jest sporny w nauce i zostanie omówiony w dalszej części pracy.
}

Abstract: The article discusses the time and circumstances of creating a well-known seventeenth-century variant of a map of the Duchy of Pomerania together with the map's cartographic sources and its role in Pomeranian cartography. Until now, the person mentioned on the map as Frid. Palbitzke has not been identified. The article reveals his identity, his role in preparing the map, and the purpose of its making.

Keywords: history of cartography, cartography of Pomerania, history of Słupsk (Stolp), 17th century, Frid. Palbitzke, Pałubicki family

działalności publicznej Pałubickiego w jego latach dojrzałych ${ }^{2}$.

Celem pracy jest przedstawienie okoliczności powstania mapy oraz roli, jaką odegrała w kartografii Pomorza Zachodniego. Mapie tej nie poświęcono dotąd żadnego szczegółowego studium ${ }^{3}$, a spostrzeżenia

${ }^{2}$ Z. Szultka, Pałubiccy - burmistrzowie, rajcy i obywatele Stupska końca XVI i pierwszej połowy XVII wieku, „Rocznik Słupski”, 1979, s. 13-15, 20-22. ${ }^{3}$ Najobszerniej na temat mapy wypowiedziat się C. Drolshagen, Neuvorpommern und Rügen im Rahmen der älteren Kartographie und Landesaufnahme, „Pommersche Jahrbücher”, 10, 1909, s. 209-212, lecz jego rozważania są w dużej mierze oparte na nieaktualnym stanie badań historii kartografii pomorskiej. Poza tym istotniejsze głosy nauki przedstawili C. Schuchhardt, Vineta, „Sitzungsberichte der Preussischen Akademie der Wissenschaften. Philosophisch-Historische Klasse", 1924, s. 201-207; M. Stelmach, Historia kartografii Pomorza Zachodniego do końca XVIII wieku, Szczecin 1991, s. 100-102; tenże, Pomorze i Szczecin na dawnych mapach, planach i widokach. Katalog wystawy, Szczecin 1998, s. 26-27; G. Loeck, Das Kartenbild von Pommern zur Hansezeit, ,Baltische Studien. Pommersche Jahrbücher für Landesgeschichte", 90, 2004, s. 132-133; M. Dworsatchek, Polska w dawnej kartografii. Historyczne ziemie polskie na mapach do początku XIX wieku w zbiorach Ossolineum, Wrocław 2008, s. 99; R. Skrycki, Wielka mapa Pomorza Eilharda Lubinusa a kartografia regionu, w: Eilharda Lubinusa podróż przez Pomorze, red. R. Skrycki, Szczecin 2013, s. 134-135. Zob. także Katalog dawnych map Rzeczypospolitej Polskiej w kolekcji Emeryka Hutten Czapskiego, t. 2: Mapy XVII wieku, oprac. T. Paćko, D. Stachnal-Talanda, E. Gołąb-Jankowska, Wrocław-Warszawa-Kraków 1992, s. 64-65. 
na jej temat pojawiające w literaturze wymagają uzupełnień i korekt. W szczególności z reguły mylnie podawany jest rok jej powstania, a zakres wprowadzonych do niej modyfikacji (np. kilkadziesiąt nowych nazw geograficznych) nie jest w pełni dostrzegany. Nie rozpoznano też dokładnie źródeł kartograficznych, na których została oparta.

Zasadne okazało się uzupełnienie biografii Pałubickiego. Do tej pory nie wiedziano, kiedy się urodził ani (co istotne dla zrozumienia okoliczności towarzyszących powstaniu mapy), że studiował w Niderlandach.

Opracowanie niniejsze nie jest wyczerpującą analizą historyczno-kartograficzną mapy. Pomija jej szczegółowy opis, zagadnienia dokładności, skali i odwzorowania, a jedynie skrótowo omawia kwestię zmienności płyty w czasie (tzw. stany mapy).

\section{Kwestia autorstwa mapy w dotychczasowej literaturze}

Jako pierwszy próbę identyfikacji autora mapy podjął Johann Oerlichs. Spostrzegł, że w dziele Johannesa Micraeliusa jest mowa o rodzie Palbitzken, należącym do „wolnych" ${ }^{4}$. Pojęciem tym obejmowano kaszubskich panków zamieszkałych w ziemi bytowskiej, których szlachecki status był kwestionowany przez książąt pomorskich. Istotnie, Pałubiccy zamieszkiwali przynajmniej od drugiej połowy XVI w. Półczno i Gostkowo w ziemi bytowskiej ${ }^{5}$, lecz byli jedną z bardzo niewielu rodzin osiadłych na tym terenie, których szlachectwo (od XVII w.) książęta uznawali'. Być

\footnotetext{
${ }^{4}$ J.C.C. Oerlichs, Zuverläßige historisch-geographische Nachrichten vom Herzogthum Pommern und Fürstenthum Rügen, Berlin 1771, s. 30-31; J. Micraelius, Sechs Bücher vom alten Pommernland, Buch 6: Von deß Pommerlandes Gelegenheit und Einwohnern, Stettin und Leipzig 1723, s. 364. ${ }^{5}$ B. Wachowiak, Pankowie w wizytacjach domeny bytowskiej z drugiej połowy XVI wieku, „Acta Cassubiana”, 8, 2006, s. 40-41.

${ }^{6}$ Z. Szultka, w: Historia Pomorza, red. G. Labuda, t. 2: do roku 1815, cz. 3: Pomorze Zachodnie w latach 1648-1815, oprac. Z. Szultka, H. Lesiński i in., Poznań 2003, s. 141; por. jednak B. Wachowiak, Pankowie, s. 25 i 40-41, z którego rozważań wynika, że jeszcze w XVI w. Pałubiccy w ziemi bytowskiej mieli taki sam status, jak inni pankowie i nie byli uznawani przez książąt za szlachtę.
}

może wiązało się to ze znacznym bogactwem i wpływami na dworze książęcym, jakie zdobyła słupska gałąź rodziny. Bliskie pokrewieństwo Pałubickich ze Słupska i z ziemi bytowskiej jest prawdopodobne, bowiem dziad Fryderyka, Maciej Pałubicki, według jednego z przekazów pełnił urząd sędziego miejskiego w Bytowie ${ }^{7}$ (zapewne zanim - jako pierwszy z rodu osiadł w Słupsku).

Za Oerlichsem informację o tym, że autor przeróbki mapy był pomorskim szlachcicem, podał Carl Drolshagen, a następnie Mieczysław Stelmach, od którego zaczerpnął ją Radosław Skrycki ${ }^{8}$. Z kolei Carl Schuchhardt nazwał autora mapy „pomorskim uczonym”, choć też nie potrafil go zidentyfikować9.

\section{Informacje biograficzne}

Fryderyk Pałubicki był synem Jerzego (zm. w 1638 r.; zwanego w literaturze Jerzym I, dla odróżnienia od jego najstarszego syna), prawnika, burmistrza Słupska i polityka pomorskiego ${ }^{10}$, oraz Anny z domu Hoppe (zm. w 1654 r.), córki Dionizego Hoppego, również prawnika i dyrektora sądu landwójtowskiego w Słupsku ${ }^{11}$.

Ponieważ w rejestrze studentów uniwersytetu w Lejdzie Fryderyka Pałubickiego odnotowano dwukrotnie, w obu przypadkach z podaniem wieku: w maju $1630 \mathrm{r}$.

\footnotetext{
${ }^{7}$ C.F. Wustrack, Nachtrag zur Kurzen historisch-geographisch-statistischen Beschreibung von dem königlich-preußischen Herzogtum Vor- und Hinterpommern, Stettin 1795, s. 329.

${ }^{8}$ C. Drolshagen, Neuvorpommern, s. 210; M. Stelmach, Historia kartografii Pomorza, s. 100; tenże, Pomorze, s. 27; R. Skrycki, w: S. Alexandrowicz, J. Łuczyński, R. Skrycki, Historia kartografii ziem polskich do końca XVIII wieku, Warszawa 2017, s. 293; tenże, Wielka mapa, s. 135; por. jednak Noty katalogowe w: Eilharda Lubinusa podróż, s. 42, gdzie trafnie utożsamiono dopisaną przez autora przeróbki miejscowość Palbitz z Pałubicami i powiązano z nazwiskiem widniejącym w tytułowym kartuszu mapy.

${ }^{9}$ C. Schuchhardt, Vineta, s. 205.

${ }^{10}$ R. Schuppius, Stolp von 1600-1650. Friedensarbeit und Kriegsnöte einer pommerschen Stadt, Stolp 1930, s. 10; Z. Szultka, Pałubiccy, s. 13; K. Ślaski, Beiträge zur Geschichte Pommerns und Pommerellens, Dortmund 1987, s. 99. Relacji takiej domyśla się także T. Rembalski, Pałubiccy z Osławy Dąbrowy, ,Pomerania”, 12, 2006, s. 31. Informacje biograficzne o Jerzym I podaje najszerzej Z. Szultka, Pałubiccy, s. 13-16.

${ }^{11}$ R. Schuppius, Die Familiennamen von Stolp und Umgebung im 16. Jahrhundert. 2. Auflage, [b.m.w.] 1930, s. 50, Z. Szultka, Pałubiccy, s. 10.
} 
(20 lat) i we wrześniu 1635 r. (26 lat) ${ }^{12}$, możemy z dużym prawdopodobieństwem przyjąć, że urodził się pomiędzy majem a wrześniem 1609 r.

Fryderyk miał czterech braci, z których o jednym, psychicznie chorym, wiadomo tylko, że żył jeszcze w 1654 r. i miał na imię Chrystian ${ }^{13}$. Z pozostałych, Jerzy (burmistrz Słupska i landrat) był nieco starszy, a Maciej (baron i dyplomata szwedzki, szambelan królowej szwedzkiej Krystyny) i Dionizy (szambelan szwedzkiej królowej matki, Marii Eleonory Brandenburskiej) - zdecydowanie młodsi ${ }^{14}$.

W wieku dziesięciu lat (22 sierpnia 1619 r.) został przyjęty (jako Fridericus Palbitzki) na Uniwersytet Królewiecki ${ }^{15}$. Wpisano go jako małoletniego (prowadzono tam też nauczanie niższego stopnia). Tego samego dnia przyjęto także jego brata Jerzego ${ }^{16}$. Nie wiadomo, jak długo obaj pobierali nauki w Królewcu. Ze wszystkich uniwersytetów ten był najbliżej Słupska.

W marcu 1628 r. (jako Fridericus Palbitzki Stolpensis, Pomer.) immatrykulował się na Uniwersytecie w Rostocku, niecałe dwa lata po bracie Jerzym ${ }^{17}$, a w maju $1630 \mathrm{r}$. (jako Fredericus Palbitzke Pomeranus) został studentem prawa Uniwersytetu Lejdejskiego, na który powrócił we wrześniu 1635 r. (jako Fredericus Palbisky Pomeranus) ${ }^{18}$,

\footnotetext{
${ }^{12}$ Album studiosorum Academiae Lugduno Batavae 1575-1875, Hagae Comitum, 1875, s. 226 i 274.

${ }^{13}$ R. Schuppius, Die Familiennamen, s. 50 - podany przez niego rok 1625 prawdopodobnie jest datą wzmianki, nie zaś urodzenia Chrystiana; Z. Szultka, Pałubiccy, s. 13-14.

${ }^{14}$ W. Nisser, Mathias Palbitzki. Som connoisseur och tecknare, Uppsala 1934, s. 16-29 i 121-133; Z. Szultka, Pałubiccy, s. 13-15.

${ }^{15}$ Die Matrikel und die Promotionsverzeichnisse der Albertus-Univesität zu Königsbergi. Pr., B. 1: Die Immatrikulationem von 1544-1656, Hrsg. G. Erler, Leipzig 1916, s. 242; por. także R. Schuppius, Die Familiennamen, s. 50; Z. Szultka, Pałubiccy, s. 13 i 25 oraz Z. Szultka, Z badań nad rodowodem i strukturą patrycjatu słupskiego w drugiej połowie XVI i w pierwszej połowie XVII wieku, „Zapiski Historyczne”, 47 (2), 1982, s. 40-41, gdzie mylnie rok 1611

${ }^{16}$ Die Matrikel und die Promotionsverzeichnisse, s. 241.

${ }^{17}$ Die Matrikel der Universität Rostock, Hrsg. A. Hofmeister, Rostock 1895, s. 71 i 74; por. także R. Schuppius, Die Familiennamen, s. 50 orazZ. Szultka, Z badań, s. 41.

${ }^{18}$ Album studiosorum, s. 226 i 274.
}

tam też studiował od kwietnia 1644 r. jego brat Dionizy ${ }^{19}$.

Jako Friederich Palbitzky wpisał się 9 grudnia 1630 r. w Lejdzie do sztambucha (album amicorum) Martinowi Dornkampfowi, innemu studentowi prawa ${ }^{20}$, a w latach 1631-1635 korespondował z niderlandzkim uczonym i humanistą Peterem van der Kunem (Petrus Cunaeus, 1586-1638) - miejsca wysyłki listów to Lejda, Haga i Słupsk ${ }^{21}$.

Wiadomo zatem, że przebywał w Niderlandach pomiędzy 1630 a przynajmniej 1635 r., zapewne z jedną przerwą. Najpóźniej w 1637 r. wrócił prawdopodobnie na stałe do domu, skoro opublikował wtedy w Gdańsku wiersz, o czym będzie jeszcze mowa. Nie ulega wątpliwości, że właśnie przy okazji studiów w Lejdzie nawiązał kontakt z oficyną wydawniczą Hondiusa-Janssoniusa ulokowaną w odległym o $40 \mathrm{~km}$ Amsterdamie.

Na mapie figuruje jako Frid. Palbitzke Pomer. L.L. Studiosum. Nie do końca prawidłowo rozwiną to Gottfried Loeck jako Pomeranum Liberalium Litterarum Studiosum $^{22}$. Skrót Pomer. istotnie oznacza narodowość. Zarówno Fryderyk Pałubicki, jak i inni członkowie jego rodziny, np. w wykazach uniwersyteckich, dopisywali po nazwisku Pomer. albo Pomeranus, ew. Nobiles Pomeranus lub Stolpensis, Pomeranus. Natomiast nawiązanie do sztuk wyzwolonych jest mylne - w chwili kreślenia mapy Fryderyk Pałubicki był studentem prawa. Skrót L.L. nie musiał oznaczać dwóch wyrazów zaczynających się na $l$, ale jeden wyraz w liczbie mnogiej: legum. Alternatywnie, choć to mniej prawdopodobne, jedna litera L. mogła oznaczać Lejdę (Lugdunum Batavorum), a druga kierunek studiów (legum).

\footnotetext{
${ }^{19}$ Tamże, s. 348.

${ }^{20}$ Królewska Biblioteka w Hadze, sygn. 131 E 6 (k. 193).

${ }^{21}$ Korespondencja znajduje się w zbiorach Biblioteki Uniwersyteckiej w Lejdzie (sygn. CUN 1A, CUN 1B i CUN 2); znam ją wyłącznie z katalogu bibliotecznego.

${ }^{22}$ G. Loeck, Das Kartenbild, s. 132.
} 
Uważam, że cały tekst nunc iterum correcta per Frid. Palbitzke Pomer. L.L. Studiosum powinien być rozwinięty jako nunc iterum correcta per Fridericum Palbitzke, Pomeranum, Legum Studiosum albo ewentualnie nunc iterum correcta per Fridericum Palbitzke, Pomeranum, Legum Lugduni [Batavorum] Studiosum, co w pierwszym wariancie oznacza: „teraz ponownie poprawiona przez Fryderyka Pałubickiego, Pomorzanina, studenta praw", a w drugim: „teraz ponownie poprawiona przez Fryderyka Pałubickiego, Pomorzanina, studenta praw w Lejdzie".

Niemiecko brzmiący wariant nazwiska (Palbitzke) stosował rzadko - preferował wersję bliższą polskiej (zakończoną na $i$ ). $\mathrm{Z}$ całą pewnością władał językami polskim $^{23}$ i niemieckim, a do tego łaciną. Przez kilka lat pobytu w Holandii musiał też nabyć pewną znajomość języka niderlandzkiego. $\mathrm{O}$ jego zainteresowaniach i umiejętnościach wiele mówi omawiana mapa. Wynika z niej, że miał dobrą orientację w geografii Pomorza (zwłaszcza Tylnego - tj. przedodrzańskiego), interesował się historią oraz że mógł mieć, podobnie jak jego brat Maciej (autor serii szkiców przechowywanych obecnie w szwedzkich muzeach) ${ }^{24}$, uzdolnienia rysunkowe.

Pomijając mapę Pomorza oraz nieprzeznaczoną do druku twórczość epistolograficzną, wiadomo tylko o jednej publikacji Fryderyka Pałubickiego: w 1637 r. w Gdańsku ukazał się zbiór wierszy upamiętniających ślub słupskiego pastora Petera Zimmermanna ${ }^{25}$. Wśród ośmiu autorów są Jerzy II i Fryderyk Pałubiccy. Natomiast w 1629 r. w Szczecinie wydano

\footnotetext{
${ }^{23}$ B. Wachowiak, w: Historia Pomorza, red. G. Labuda, t. 2: Do roku 1815, cz. 1: 1464/66-1648/57, oprac. M. Biskup i in., Poznań 1976, S. 1014.

${ }^{24}$ Monografia nt. Macieja Pałubickiego: W. Nisser, Mathias Palbitzki, gdzie także reprodukcje jego rysunków.

${ }^{25}$ J. Praetorius, A. Blenno, G. Palbitzky, F. Palbitzky i in., 'EnıӨałápıa in Honorem ac Celebritatem Nuptiarum PI. Reverendi, Clarissimi et Doctissimi Viri Dn. M. Petri Zimmermanni Pastoris Ecclesiae Stolpicae, Dantisci 1637, Elektroniczna Baza Bibliografii Estreichera (https://www.estreicher. uj.edu.pl/staropolska/baza/wpis/?sort=id\&order $=1 \&$ offset $=47129 \&$ i$d=163098$ \&index =21, dostęp: 25 lutego 2019).
}

dzieło Martina Leuschnera (1598-1641), zadedykowane m.in. Fryderykowi ${ }^{26}$.

Od 1648 r. był żonaty z Katarzyną Labuhn, córką Konrada Labuhna, innego burmistrza słupskiego (największego adwersarza jego ojca, Jerzego ${ }^{27}$. Nie jest jasne, czy Katarzyna była pierwszą małżonką Fryderyka, o którym wiadomo, że na początku lipca 1654 r. miał młodą żonę i pięcioro dzieci ${ }^{28}$. Musiałyby się więc rodzić rok po roku (o ile nie było ciąż mnogich) i do tego wszystkie przeżyć. Mógł zatem mieć już wcześniej żonę i owdowieć, zanim w wieku ok. 38 lat ożenił się ponownie. Katarzyna, wraz z jakąś córką Fryderyka, zmarła w $1660 \mathrm{r}^{29} \mathrm{O}$ innych (przynajmniej czworgu) jego dzieciach nic nie wiadomo.

Działalność publiczną Fryderyka Pałubickiego zbadał Zygmunt Szultka, który omówił jego karierę urzędniczą, w tym funkcje: starszego gildii kupieckiej (od 1648 r.), prowizora słupskich kościołów i szkół (w latach 1649-1651), rajcy (od 1649 r.), burmistrza (od 1651 r.) i landrata (od 1653 r.) - karierę tę z pewnością ułatwiał fakt, że dwaj jego bracia należeli do wpływowych osobistości na dworze szwedzkim, a w latach 1630-1653 Pomorze Zachodnie było pod szwedzką okupacją ${ }^{30}$. Fryderyk był ostatnim przedstawicielem burmistrzowskiej „dynastii” Pałubickich i ostatnim w ogóle szlacheckim burmistrzem Słupska ${ }^{31}$.

O działalności Pałubickiego informacje podają także inni autorzy, lecz nie wnoszą nic ponad ustalenia Szultki.

\footnotetext{
${ }^{26}$ M. Leuschner, Disputationum ethicarum I-IX, Stetini 1629. Z tych dysput druga (De Summo Bono Quam Jehova auxiliante) została zadedykowana Fryderykowi, a ósma (De Justitia Et Jure. Quam Duce \& auspice Christo) m.in. jego ojcu.

${ }^{27}$ Z. Szultka, Pałubiccy, s. 14; R. Schuppius, Die Familiennamen, s. 37 i 50 ; tenże, Stolp, s. 10, przy czym Schuppius nie znał jej imienia.

${ }^{28}$ Z. Szultka, Pałubiccy, s. 14.

${ }^{29}$ Tamże.

${ }^{30}$ Tamże, s. 13-15 oraz 20-22; Z. Szultka, Z badań, s. 43-47; Pomorze Zachodnie pod rządami książąt plemiennych i władców z dynastii Gryfitów (990-1121-1637-1648/53), wyd. Z. Szultka, Poznań-Gdańsk 2006 (Żródła do kaszubsko-polskich aspektów dziejów Pomorza Zachodniego do roku $1945,1)$, s. 582-583

${ }^{31}$ Z. Szultka, Z badań, s. 45-46; J. Lindmajer i in., Dzieje Stupska, Słupsk 1986, s. 155.
} 
Z dawniejszych badaczy, Christian Wustrack odnotował go jako burmistrza słupskiego w 1653 r., natomiast jeden z dokumentów opublikowanych przez Johanna Jacoba Mosera podaje go w 1654 r. jako burmistrza i landrata ${ }^{32}$. Choć Gustav Kratz nie cytuje tych autorów, nie ulega wątpliwości, że to właśnie połączenie informacji od nich zaczerpniętych jest przyczyną tego, że w jego wykazie Fryderyk został podany jako burmistrz w latach 1653 i 1654 ze wskazaniem, że był także landratem ${ }^{33}$. Nie wydaje się słuszny zarzut Szultki, że Kratz podał błędnie czas pełnienia urzędu przez Pałubickiego $^{34}$ - niemiecki historyk wskazał tylko dwa lata, o których wynotował, że pełnił on w nich funkcję burmistrza i nie twierdził bynajmniej, że jest to informacja wyczerpująca. Za Kratzem wiadomość o tym podali też Walther Bartholdy ${ }^{35}$ oraz Kazimierz Ślaski ${ }^{36}$. Według innej publikacji tego ostatniego, Fryderyk Pałubicki był burmistrzem w 1649 r., co nie jest praw$\mathrm{da}^{37}$. Natomiast według Richarda Schuppiusa pełnił funkcję rajcy od $1649 \mathrm{r}$. oraz burmistrza $^{38}$. O burmistrzostwie w $1653 \mathrm{r}$. i landraturze (mylnie opisanej jako funkcja „starosty słupskiego”) pisze także Tomasz Rembalski ${ }^{39}$.

Zygmunt Szultka omówił szeroko kwestię powołania w $1649 \mathrm{r}$. i funkcjonowania szkoły polskiej w Słupsku, zainicjowanej, bronionej i popieranej przez braci Pałubickich: Jerzego II i Fryderyka (obaj byli kolejno rajcami i prowizorami szkół, a następnie burmistrzami) wbrew silnej

\footnotetext{
${ }^{32}$ C.F. Wustrack, Nachtrag, s. 330; J.J. Moser, Landeshoheit in Regierungssachen überhaupt, Franckfurt-Leipzig 1772, s. 225. Obie te publikacje nie zostały dostrzeżone przez Zygmunta Szultkę.

${ }^{33}$ G. Kratz, Die Städte der Provinz Pommern, Berlin 1865, s. 432.

${ }^{34}$ Z. Szultka, Pałubiccy, s. 25.

${ }^{35}$ W. Bartholdy, ,, O Stolpa, du bist ehrenreich..." kulturgeschichtliche Beiträge zur Kirchen- und Stadtgeschichte von Stolp, Stolp 1910, s. 65 (lecz por. takìe s. 60).

${ }^{36}$ K. Ślaski, Polskość Pomorza zachodniego w świetle źródet XVI-XVIII w., w: Pomorze nowożytne, red. G. Labuda, S. Hoszowski, Warszawa 1959 (Szkice z dziejów Pomorza, 2), s. 49.

${ }^{37}$ K. Ślaski, Beiträge, s. 99-100.

${ }^{38}$ R. Schuppius, Die Familiennamen, s. 50; tenże, Stolp, s. 10.

${ }^{39}$ T. Rembalski, Pałubiccy, s. 31.
}

opozycji kręgów niemieckich w mieście. Jego zdaniem ustąpienie Jerzego II z funkcji burmistrza latem 1651 r., a następnie wycofanie się przez Fryderyka z godności we władzach miasta latem $1654 \mathrm{r}$. mogło być związane z tym sporem ${ }^{40}$. Szkoła działała przynajmniej do 1663 r. ${ }^{41}$ Również ojciec Fryderyka, Jerzy I działał w kierunku utworzenia w Słupsku polskiej szkoły ok. 1622 r., choć zapewne bezskutecznie ${ }^{42}$.

Opór przeciwko szkole polskiej nie może dziwić wobec silnej nietolerancji skutkującej dyskryminacją ludności kaszubskiej na Pomorzu Zachodnim. Tym bardziej należy docenić determinację Pałubickich (dwóch Jerzych i Fryderyka), postępujących wbrew wpływowym kręgom w Słupsku, prawdopodobnie gotowych stawiać sprawę szkolnictwa polskiego na ostrzu noża, rezygnując nawet (permanentnie lub czasowo) z własnej kariery. Istniała w mieście liczna grupa mieszkańców, którzy chcieli kształcić swoje dzieci choćby w podstawowym zakresie, a jednocześnie nie zamierzali rezygnować z własnej mowy (znajomość niemieckiego nie była wtedy w Słupsku powszechna poza wyższymi warstwami mieszczaństwa). To dla

\footnotetext{
${ }^{40}$ Z. Szultka, Pałubiccy, s. 20-22. We wcześniejszej pracy (Z. Szultka, Z problematyki stosunków etnicznych Słupska i okolicy w XIV-XVIII wieku, „Rocznik Koszaliński”, 11, 1975, s. 60), przypisywał on zasługę założenia szkoły Fryderykowi Pałubickiemu (podobnie K. Ślaski, Beiträge, s. 99-100), lecz w późniejszej publikacji (Z. Szultka, Pałubiccy, s. 20-22) nie podtrzymał tego stanowiska - w chwili założenia szkoły Fryderyk nie pełnił jeszcze żadnej funkcji miejskiej. Ta zasługa raczej powinna być przypisana Jerzemu II, natomiast późniejsze popieranie szkoły przez Fryderyka jest udokumentowane. 0 szkole polskiej por. także Pomorze Zachodnie pod rządami książąt plemiennych, s. 582-583 oraz Z. Szultka, w: Historia Pomorza, t. 2, cz. 3, s. 221.

41 Z. Szultka, w: Historia Pomorza, t. 2, cz. 3, s. 221. Dawniej uważano, że szkoła została zlikwidowana już w 1654 r., tak: Z. Szultka, Z problematyki, s. 60; B. Wachowiak, w: Historia Słupska, red. S. Gierszewski, Poznań 1981, s. 172; K. Ślaski, Beiträge, s. 99.

${ }^{42}$ R. Schuppius, Stolp, s. 45; K. Ślaski, Przemiany etniczne na Pomorzu Zachodnim w rozwoju dziejowym, Poznań 1954, s. 178-179; tenże, Polskość Pomorza, s. 43; H. Kaczmarczyk, Szkice słupskie (XVI-XVII w.), w: Szkice słupskie. Praca zbiorowa, red. A. Benesz i in., Poznań-Słupsk 1960, s. 14-15; J. Freith i in., Kronika najważniejszych wydarzeń z dziejów miasta Słupska i powiatu słupskiego, w: tamże, s. 47; B. Dopierała, Polskie losy Pomorza Zachodniego, Poznań 1970, s. 144; Z. Szultka, Z problematyki, s. 60; B. Wachowiak, w: Historia Pomorza, t. 2, cz. 1, s. 1014; tenże, w: Historia Słupska, s. 172; K. Ślaski, Beiträge, s. 99. Temat szczegółowo analizuje Z. Szultka, Pałubiccy, s. 25, s. 18-20.
} 
tej grupy działali Pałubiccy, niewątpliwie ciesząc się jej poparciem. Wszyscy trzej burmistrzowie z pewnością utrzymywali żywe kontakty z krewnymi funkcjonującymi w środowiskach całkowicie polskich, czy to w ziemi bytowskiej, czy w Prusach Królewskich. Słupskich Pałubickich, protestantów oraz lojalnych poddanych książąt pomorskich i elektorów brandenburskich, wiązało z Polską pochodzenie, więzy pokrewieństwa po mieczu i język.

Fryderyk Pałubicki zmarł kilka dni przed 27 kwietnia 1658 r., w wieku 49 lat ${ }^{43}$.

\section{Wielka mapa Lubinusa i jej pierwsza wersja atlasowa}

Ukończona w 1618 r. wielka, dwunastoarkuszowa mapa Księstwa Pomorskiego autorstwa Eilharda Lubinusa (Eilert Lübben, 1565-1618) ma obszerną bibliografię ${ }^{44}$ i nie trzeba jej szczegółowo omawiać. Dla dalszego wywodu istotne jest, że było to wybitne osiagnięcie ówczesnej kartografii, oparte na podstawach naukowych i szeroko zakrojonych pomiarach w terenie. W związku z tym mapa ta stanowiła oczywisty wzór dla wydawców atlasów, wymagający jednak redukcji oraz selekcji zawartego w niej materiału.

Płytę z dostosowaną do formatu atlasowego mapą (zwę ją dalej pomniejszoną lub zredukowaną mapą Lubinusa) kazał sporządzić i pierwotnie posiadał Jodocus Hondius młodszy, syn znanego wydawcy map o tym samym imieniu. Jedyne wydanie jego atlasu przygotował w połowie 1629 r. on sam (zmarł w sierpniu 1629 r.) lub jego żona. Druk nastąpił z płyt przygotowanych do prezentacji na frankfurckich targach (jesień 1629 r.). Atlas nosi datę

\footnotetext{
${ }^{43}$ Z. Szultka, Pałubiccy, s. 14; J. Lindmajer i in., Dzieje Stupska, s. 155. Inaczej K. Ślaski, Beiträge, s. 100, który mylnie twierdził, że Fryderyk Pałubicki zmart w 1654 r.

${ }^{44}$ Obecnie referencyjnymi pracami są R. Skrycki, Wielka mapa; J. Szeliga, Dokładność mapy Pomorza Eilharda Lubinusa, w: Eilharda Lubinusa podróż oraz E. Gwiazdowska, 0 ikonografii Wielkiej Mapy Księstwa Pomorskiego Eilharda Lubinusa, w: tamże; ze starszych pozycji godne są uwagi: M. Stelmach, Historia kartografii Pomorza, s. 59-97 i tenże, Eilhardus Lubinus i jego wielka mapa Księstwa Pomorskiego, Szczecin 2001.
}

wydania 1630 i jest dziś znany z pięciu istotnie różniących się między sobą egzemplarzy ${ }^{45}$.

Rytownikiem zredukowanej mapy Lubinusa był Salomon Rogiers (sygnował ja). Nie wiadomo natomiast, kto wyselekcjonował materiał $\mathrm{z}$ wielkiej mapy i sporządził na jej bazie pomniejszenie. Wątpliwe, że był to Rogiers ${ }^{46}$ - jako sztycharz (rzemieślnik nanoszący na miedzianą płytę negatyw dostarczonej mapy), a nie kartograf, zapewne nie miał do tego kwalifikacji. Bardziej prawdopodobne, że redukcji dokonał sam Hondius ${ }^{47}$.

Pomniejszona mapa dość wiernie odzwierciedla oryginał, lecz redukcja pociągnęła za sobą zubożenie zarówno informacji kartograficznej (zmniejszono ilość miejscowości, ubyły nazwy niektórych obiektów hydro- i fizjograficznych), jak i strony estetycznej (znikły herby, widoki miast itp.).

Po śmierci Jodocusa Hondiusa młodszego płytę tę, wraz z grupą około czterdziestu innych, zakupił Willem (Janszoon) Blaeu ${ }^{48}$, którego oficyna używała jej od 1630 r. przez wiele lat przy produkcji swych atlasów. Wątpliwe, by nabycie płyt przez Blaeua nastąpiło jeszcze przed śmiercią Hondiusa $^{49}$. Mylna jest też teza, że płyty sprzedali Blaeuowi omówieni poniżej Henricus Hondius i Johannes Janssonius

\footnotetext{
${ }^{45}$ P. van der Krogt, Koeman's Atlantes Neerdlandici, New Edition, vol. 1: The Folio Atlases Published by Gerard Mercator, Jodocus Hondius, Henricus Hondius, Johannes Janssonius and Their Successors, 't Goy-Houten 1997, s. 125-127; por. także C. Koeman, Atlantes Neerlandici. Bibliography of terrestrial, maritime and celestial atlases and pilot books published in the Netherlands up to 1880, vol. 2: Blussé-Mercator, Amsterdam 1969, s. 347. R. Skrycki, w: Historia kartografii ziem polskich, s. 293, podaje rok 1630 r.; Katalog, s. 65 zaś - zupełnie mylnie - 1621; M. Stelmach, Historia kartografii Pomorza, s. 100 - ok. 1620, w późniejszej publikacji (tenże, Pomorze, s. 25), podał już $1630 \mathrm{r}$.

${ }^{46}$ Tak Noty katalogowe, s. 42.

${ }^{47}$ Tak M. Stelmach, Pomorze, s. 25; podobnie zdaje się uważać C. Koeman, Atlantes, s. 347.

${ }^{48}$ C. Koeman, Atlantes, s. 344; P. van der Krogt, Koeman's, s. 37, 123, 125-127. R. Skrycki, w: Historia kartografii ziem polskich, s. 293, mylnie podał jako nabywcę płyt Joana Blaeua zamiast jego ojca Willema.

${ }^{49}$ Taką możliwość widział R.A. Skelton w: Mercator - Hondius - Janssonius Atlas or Geographicke description of the World [reprint], t. 1, Amsterdam 1968 , s. XII.
} 
jako spadkobiercy Jodocusa Hondiusa ${ }^{50}$. Byłoby to zupełnie niezrozumiałe, skoro brak tych płyt był dla nich tak dotkliwy, że musieli je prawie natychmiast odtwarzać znacznym nakładem kosztów. W rzeczywistości zostali oni uprzedzeni w kupnie płyt przez Blaeua. Osobą sprzedającą płyty była najpewniej wdowa po Jodocusie Hondiusie młodszym.

\section{Powstanie mapy Fryderyka Pałubickiego, kwestia autorstwa}

W Amsterdamie działała też inna firma wydawnicza, kontynuująca tradycje Atlasu Gerarda Mercatora oficyna prowadzona przez Henricusa Hondiusa (brata Jodocusa) i jego szwagra Johannesa Janssoniusa. $\mathrm{Z}$ niezadowoleniem przyjęli oni wiadomość o pojawieniu się nowego gracza na rynku, Willema Blaeua, który zaczął z nimi konkurować przy użyciu płyt stworzonych przez ich brata i szwagra. Natychmiast podjęli przeciwdziałania. Już 11 marca 1630 r. zawarli umowę z rytownikami Evertem Hamersveltem i Salomonem Rogiersem, zlecając im wykonanie kopii 36 płyt, czyli prawie wszystkich, które kupił Blaeu. Zgodnie z kontraktem rytownicy mieli osiemnaście miesięcy na dokładne skopiowanie map konkurenta, wśród których znalazła się także zredukowana mapa Lubinusa. Wydawcy postawili warunek, że nowe płyty mają być lepsze niż oryginały ${ }^{51}$.

Twierdzenie Mieczysława Stelmacha, że Henricus Hondius i Johannes Janssonius już w 1630 r. umieścili w swym atlasie nową mapę Pomorza, opartą na wielkiej mapie Lubinusa, lecz sporządzoną w sposób uproszczony i niedbały, z mniejszą liczbą miejscowości, zubożoną siecią hydrograficzną, bez lasów, łąk i mokradet ${ }^{52}$ jest mylne, przynajmniej jeśli chodzi o atlasy pełnowymiarowe (in folio). W całym okresie pomiędzy utratą płyt sprzedanych

\footnotetext{
${ }^{50}$ Tak uważał M. Stelmach, Pomorze, s. 25.

${ }^{51}$ C. Koeman, Atlantes, s. 344-346; P. van der Krogt, Koeman's, s. 124-125. Por. także M. Stelmach, Historia kartografii Pomorza, s. 100.

${ }_{52}$ M. Stelmach, Historia kartografii Pomorza, s. 100.
}

Blaeuowi (1630), a ukazaniem się w $1632 \mathrm{r}$. atlasu z mapą Pałubickiego, wydawcy ci wypuścili na rynek trzy lub ewentualnie cztery wydania atlasów in folio, z których żaden nie zawierał mapy Pomorza (jeden zawierał mapę Brandenburgii, Meklemburgii i części Pomorza autorstwa Claesa Janszoona Visschera) ${ }^{53}$.

Z 36 kopii płyt zleconych rytownikom wykonano ostatecznie 35, z czego jedna prawdopodobnie była przeróbką starszej płyty. Z tych 34 nowych płyt osiemnaście porównałem szczegółowo do ich oryginałów używanych przez Blaeua ${ }^{54}$. Na pięciu mapach nie wprowadzono żadnych widocznych modyfikacji (Groninga Dominium, Frisia Occidentalis, Mappa Astivarum Insularum, Perv, Gviana siue Amzonvm Regio). Na dalszych sześciu zmieniono tylko południk zerowy ( $T y$ pvs Fisia Orientalis, Alpina seu Foederate Rhatia descriptio, Austria Archiducatvs, Meklenburg Dvcats, Prussia Accurate Descripta, Dvcatvs Lvnebvrgensis). Na trzech zmiany dotyczyły kartuszy (Montisferattti Dvcatus, Nova Virginic Tabula, Venezuela). Na mapie Terrra Firma et Novum Regnum Granatense obszar pokrycia został minimalnie przemieszczony, dlatego nastąpiły niewielkie zmiany współrzędnych, poza tym zmieniono ozdobniki jednego z kartuszy. Na mapie Chili dorysowano bieg jednej większej rzeki, lecz treść kartograficzna poza tym pozostała bez zmian; zmodyfikowano kartusze i róże wiatrów (okręty i potwory morskie bez zmian). Na mapie Insularum Moluccarum Nova descriptio powiększono obszar pokrycia i nieco zmodyfikowano treść kartograficzną (poza tym zmieniono kartusze, róże wiatrów, potwory, statki). Na omawianej tu mapie Nova Illustrisimi Dvcatvs Pomeranice

\footnotetext{
${ }^{53}$ P. van der Krogt, Koeman's, s. 127-134, chodzi 0 atlasy (numeracja van der Krogta): nr: 1:202 (Appendix, J. Janssonius, 1630), 1:203 (Appendix, H. Hondius, 1631), 1:211 (Theatrum Universae Galliae, J. Janssonius), oraz hipotetyczny atlas 1:212 (Theatrum Universae Galliae, H. Hondius). ${ }^{54}$ Numery map z kontraktu z rytownikami: 1-5, 8, 10, 13, 16, 18, 26, 29-32, $34-36$.
} 
Tabula pojawiła się zupełnie nowa treść pokrywająca istotną część płyty, opisano wyspy i liczne rzeki, zmieniono siatkę geograficzną, dodano kartusze i wprowadzono wiele innych zmian.

Jak widać, zdecydowana większość map została skopiowana bez jakichkolwiek istotnych zmian ${ }^{55}$. Na tle zbadanej losowo próbki, oprócz mapy Moluków (użytej po raz pierwszy w 1633 r. $^{56}$ ), tylko mapa Pomorza przerobiona przez Pałubickiego zawiera jakiekolwiek znaczniejsze zmiany dotyczące treści geograficznej, jest więc wyjątkowa.

Inicjatywa zmodyfikowania mapy raczej nie wyszła w tym przypadku od wydawców. Działali pod presją czasu i nie wydaje się, żeby chcieli wtedy dokonywać takich innowacji. Gdyby przejawiali tego typu inicjatywę, także inne skopiowane wówczas mapy zawierałyby istotne wariacje. W mojej opinii to Pałubicki, który w 1630 lub 1631 r. (przebywał w Niderlandach od maja 1630 r.) zetknął się ze zredukowaną mapą Lubinusa (wydaną jeszcze przez Hondiusa lub raczej już przez Blaeua), zgłosił do niej uzasadnione zastrzeżenia (zwłaszcza do bardzo ograniczonej prezentacji obszarów poza granicami Księstwa Pomorskiego) i zaproponował Janssoniusowi jej modyfikację. Taka propozycja musiała być dla wydawcy atrakcyjna. W końcowej części pracy omówię rzeczywistą motywację stojącą za ofertą złożoną Janssoniusowi przez Pałubickiego.

Rywalizacja pomiędzy wydawcami polegała głównie na ciągłym zwiększaniu liczby map w atlasach. Skoro Blaeu drukował mapę Lubinusa (pomniejszona), oficyna konkurencyjna także potrzebowała analogicznego produktu. W takich razach pojawienie się lokalnej osobistości, która (z reguły bez wynagrodzenia, a jedynie za

\footnotetext{
${ }^{55}$ Nie wszędzie dotartem do najwcześniejszych stanów obu porównywanych map - możliwe, że zidentyfikowane przeze mnie różnice mają późniejszą metrykę, więc w rzeczywistości skopiowane mapy byłyby jeszcze bardzie podobne do oryginatów.

${ }^{56}$ P. van der Krogt, Koeman's, s. 709
}

sam honor zaistnienia w tak prestiżowej publikacji) podejmowała się sporządzenia mapy znanych sobie okolic, było mile widziane. Jeśli taka mapa już istniała, wystarczała przeróbka zastanego wzoru, która mogłaby być sprzedana jako ulepszenie produktu konkurencji. Pozwalało to podkreślić wyższość własnego, „najaktualniejszego" atlasu, nad publikacją konkurenta, który ciągle posługiwał się mapą „przestarzałą”. Takiego chwytu użył też Janssonius, który wydrukował mapę z informacją nunc iterum correcta per Frid. Palbitzke, podkreślając przewagę nowszej mapy, „poprawionej”, nad dawniejszą (w domyśle wymagającą poprawy). Nie była to zresztą czcza przechwałka - wcześniejsza mapa była w istotnych aspektach gorsza.

Uważam, że wobec takiego rozwoju sytuacji mapa Pomorza trafiła na dalsze miejsce na liście płyt do wyrytowania (pierwotnie w kontrakcie miała numer 10), w oczekiwaniu na dostarczenie ulepszonej jej wersji. Tłumaczy to, dlaczego nie pojawiła się jeszcze $\mathrm{w}$ atlasach Janssoniusa i Hondiusa wydanych w latach 1630-163157. Przypominam, że zgodnie z umową z rytownikami wszystkie płyty miały być gotowe najpóźniej we wrześniu 1631 r. - w rzeczywistości rytowanie trwało chyba dłużej, ponieważ część map, zwłaszcza terenów pozaeuropejskich, pojawiła się po raz pierwszy w atlasach Hondiusa i Janssoniusa dopiero w późniejszych latach.

Mapy Pałubickiego po raz pierwszy użyto w atlasie wydanym w 1632 r. przez Janssoniusa ${ }^{58}$. Choć okoliczność ta została ustalona ponad wszelką wątpliwość i podana

\footnotetext{
${ }^{57}$ M. Stelmach, Historia kartografii Pomorza, s. 100, stwierdzit, że mapa F. Palbitzkego nie znajdowała się wśród płyt wyrytowanych w ramach kontraktu przez Salomona Rogiersa i Everta Hamersvelta, ponieważ nie nosi podpisu rytownika, a jego zdaniem sztycharze ci zawsze sygnowali swoje płyty. W rzeczywistości jednak umowa z Rogiersem i Hamersveltem wyraźnie wymienia mapę Pomorza ( $\mathrm{nr} 10$ ), a nie jest prawdą, że wszystkie ich płyty są sygnowane - by nie szukać daleko, brak jej na mapie sąsiadującej z Pomorzem Meklemburgii (Meklenbvrg Dvcats - nr 8 w umowie ze sztycharzami). Nie ulega więc wątpliwości, że ci dwaj rytownicy stworzyli także płytę mapy Pałubickiego.

${ }^{58}$ J. Janssonius, Theatrum Imperii Germanici, Amstelodami 1632, mapa nr 68.
} 
w referencyjnej publikacji z zakresu bibliografii opisowej atlasów ponad pół wieku temu, a następnie w jej mocno zrewidowanej wersji ponownie prawie ćwierć wieku temu ${ }^{59}$, nawet $\mathrm{w}$ najnowszej literaturze polskiej i niemieckiej podaje się z reguły błędnie rok jej pierwszego wydania ${ }^{60}$.

Mapa nie mogła powstać przed 1630 r., bowiem dopiero wtedy Blaeu zaczął się posługiwać pomniejszoną mapą Lubinusa, a Pałubicki przybył do Niderlandów. Co więcej, gdyby była gotowa przed $1631 \mathrm{r}$., zostałaby użyta w atlasie Appendix Henricusa Hondiusa ${ }^{61}$, wydanym właśnie w 1631 r. Powstała zatem w 1631 lub na początku $1632 \mathrm{r}$.

Co do wkładu osoby podpisanej jako Frid. Palbitzke w opracowanie mapy, $\mathrm{w}$ nauce zarysowały się dwa stanowiska. Zgodnie z pierwszym, prezentowanym w literaturze niemieckiej i polskiej, zarówno dawniejszej, jak i nowszej, był on po prostu autorem mapy lub dokonał jej ponownego opracowania. Wskazywali na to badacze traktujący to zagadnienie na marginesie swych rozważań ${ }^{62}$, lecz także (co znacznie ważniejsze) zajmujący się szczegółową analizą poszczególnych wprowadzonych do mapy zmian i przypisujący wszystkie te zmiany właśnie jemu ${ }^{63}$. Odmienny pogląd, o umiarkowanym lub bardzo małym udziale osoby podpisanej na mapie prezentowany jest w nowszej nauce

\footnotetext{
${ }^{59}$ C. Koeman, Atlantes, s. 354; P. van der Krogt, Koeman's, s. 137 i 598. Koeman opisał dokładniej mapę Pałubickiego dopiero przy atlasie z $1633 \mathrm{r}$. (s. 357), na skutek czego nie dostrzegano, że zaznaczył ją także jako wchodzącą w skład wydania z 1632 r. Natomiast błąd taki nie był już możliwy po ukazaniu się dzieła van der Krogta.

${ }^{60}$ Prawidłowo rok 1632 podaje M. Dworsatchek, Polska, s. 99. Ograniczając się wyłącznie do prac powstałych już po wydaniu dzieła van der Krogta, na 1633 jako rok wydania mapy mylnie wskazują: G. Loeck, Das Kartenbild, s. 133; M. Stelmach, Pomorze, s. 26; R. Skrycki, w: Historia kartografii ziem polskich, s. 293; Noty katalogowe, s. 42; R. Skrycki, Wielka mapa, s. 135; z kolei J.A. Wendt, Skarby kartografii, Warszawa 2013, s. 104, podaje rok 1645.

${ }^{61} 0$ tym atlasie por. P. van der Krogt, Koeman's, s. 130-132.

${ }^{62}$ C. Schuchhardt, Vineta, s. 205; W. Hartnack, Die Küste Hinterpommerns unter besonderer Berücksichtigung der Morphologie, Greifswald 1926, s. 15; G. Loeck, Das Kartenbild, s. 132. F. Palbitzke został też wprost nazwany autorem mapy przez M. Stelmacha (Historia kartografii Pomorza, s. 100), który później zmodyfikował swoje stanowisko (por. poniżej).

${ }^{63}$ C. Drolshagen, Neuvorpommern, s. 210-212; Katalog, s. 65.
}

polskiej ${ }^{64}$. Najpełniej rozwinął go Radosław Skrycki, którego zdaniem pomorski szlachcic jedynie dostarczył informacje, które umożliwity samemu Janssoniusowi ponowne wykonanie mapy wzorowanej na używanej przez Blaeua, a niezależnie od tych informacji, Janssonius wprowadził do nowej mapy także inne, które samodzielnie zaczerpnął $\mathrm{z}$ wielkiej mapy Lubinusa ${ }^{65}$.

Zajmuję tu stanowisko bliższe poglądowi pierwszemu. Jestem skłonny przypisać Pałubickiemu zarówno pomysł sporządzenia mapy, jak i decydujący wkład merytoryczny, a nawet zainicjowanie pewnych rozwiązań stricte graficznych. Jednocześnie, nie ulega mojej wątpliwości niemały udział rytownika w graficznym opracowaniu mapy, dopuszczam także możliwość, że to on, według instrukcji Pałubickiego, dokonał skopiowania na nową mapę części treści kartograficznej ze wskazanego źródła ${ }^{66}$.

Jak już wskazałem, w kontrakcie pomiędzy Janssoniusem i Hondiusem a sztycharzami podkreślono, że nowe płyty miały być dokładnymi kopiami płyt używanych przez Blaeua. Wyklucza to wprowadzanie istotniejszych zmian zarówno $\mathrm{z}$ inicjatywy rytowników, jak i wydawców. Jeżeli Janssonius chciałby modyfikować mapy z płyt zakupionych przez Blaeua, niewątpliwie zrobiłby to na szerszą skalę. Fakt, że nie tylko nie podjął w tym kierunku działań, ale nawet wprost poinstruował rytowników, żeby dokładnie skopiowali płyty, oznacza, że nie miał takiego zamiaru, a inicjatywa wprowadzenia zmian w mapie Pomorza nie pochodziła od niego. W tym kontekście mapa Pomorza jest zupełnie wyjątkowa na tle innych, kopiowanych wówczas dla Janssoniusa i Hondiusa z płyt Blaeua. Jako jedyna (poza mapą Moluków) ze zbadanych przeze mnie map zawiera istotniejsze zmiany w stosunku do odpowiedniej mapy wyjściowej. Także jako

\footnotetext{
${ }^{64}$ M. Stelmach, Pomorze, s. 26; M. Dworsatchek, Polska, s. 99; R. Skrycki w: Historia kartografii ziem polskich, s. 293.

${ }^{65}$ R. Skrycki w: Historia kartografii ziem polskich, s. 293.

${ }^{66}$ Kwestie te omawiam szerzej w kolejnym rozdziale.
} 
jedyna zawiera nazwisko osoby wnoszącej jakiśs wkład w powstanie mapy. Trudno przyjąć, że w tym jednym przypadku, kiedy mapa wskazuje taką osobę, większość wprowadzonych zmian miałaby pochodzić właśnie nie od niej, a od wydawcy lub rytownika, podczas gdy na innych płytach (które żadnych dodatkowych osób nie wskazuja) ani wydawca, ani rytownicy zasadniczo nie wprowadzali zmian (także czysto graficznych, mających podnieść atrakcyjność map). Nie wiadomo, dlaczego właśnie w tej jednej mapie Janssonius miałby chcieć wprowadzać zmiany i dlaczego zmiany te należy przypisać jemu lub rytownikowi, skoro sam Janssonius wskazał Pałubickiego na adresie wydawniczym mapy, jako osobę która „poprawiła” (czyli według mnie ulepszyła) dzieło Lubinusa, a nie wskazał w tym charakterze nikogo innego. Fakt, że przeróbka stanowi kompilację przynajmniej czterech innych map, nie licząc mapy Blaeua (o czym poniżej), przy czym niektóre zmiany świadczą o znajomości terenu oraz lokalnej topoi hydronimii, także przemawia za istotnym wkładem pracy Pałubickiego.

Podsumowując, uznaję Fryderyka Pałubickiego za autora omawianej przeróbki mapy, przy uwzględnieniu jednak pewnego wkładu rytownika. Autorstwo słupszczanina miało charakter umiejętnej kompilacji (od siebie wniósł niewiele).

\section{Użycie w atlasach, stany mapy, tekst na odwrocie}

Mapa Pałubickiego ukazała się w 23 wydaniach atlasów oficyny Hondiusa-Janssoniusa i ich następców w latach $1632-1681^{67}$. W ostatniej edycji ${ }^{68}$ dorytowano (zgodnie ze zmieniającą się moda) siatkę kartograficzną, zmieniono południk zerowy, dodano liczbę XII (mylnie, powinno być IIX, mapa miała bowiem $w$ atlasie numer

\footnotetext{
${ }^{67}$ Lista atlasów: P. van der Krogt, Koeman's, s. 598, por. także G. Loeck, Das Kartenbild, s. 133

${ }^{68}$ M. Pitt, J. Janssonius van Waesbergen, S. Swart, The English Atlas, vol. 2 Oxford 1681, mapa nr 8.
}

ósmy) i zmieniono adres wydawniczy na Sumptibus Janssonio-Waesbergionum, Moses Pitt et Stephani Swart ${ }^{69}$.

Bracia Johannes i Gillis Janssonius van Waesberger (wnukowie Johannesa Janssoniusa) sprzedali w $1694 \mathrm{r}$. należące do nich płyty, w tym tę zawierającą mapę Pałubickiego, Gerardowi Valkowi i Petrusowi Schenkowi ${ }^{70}$, którzy następnie wykorzystywali je we własnych atlasach. Zmienili ponownie adres wydawniczy (na Prostant Amstelaed: apud Petrum Schenk et Gerardum Valk). W późniejszych wydaniach wprowadzono dalsze zmiany: zaznaczono podział na Pomorze Przednie (VOOR POMERN) i Tylne (HINTERN POMERN) i dodano symbol twierdzy (zastosowany wobec Szczecina i Kalisza Pomorskiego) ${ }^{71}$.

Mapy zawarte w atlasie zawierały z reguły na odwrocie opis (tak zwany tekst in verso). Dla mapy Pałubickiego istniał on po łacinie, angielsku, niemiecku, francusku, hiszpańsku i niderlandzku (w tych językach były drukowane atlasy ją zawierające). Wyjątkiem jest pierwsze użycie w atlasie z 1632 r., kiedy to mapa ukazała się bez żadnego tekstu ${ }^{72}$. Mogło to, moim zdaniem, wynikać z pośpiechu Janssoniusa - potrzeby szybkiego przeciwdziałania wysiłkom Blaeua. Peter van der Krogt tłumaczy brak tekstu faktem, że wydania z lat 1630-1632 miały służyć głównie zasilaniu atlasów sztucznych (kompilacji), co również jest prawdopodobne ${ }^{73}$.

Poza wydaniami atlasowymi mapa ta była także drukowana do sprzedaży luzem. Takie egzemplarze często włączano do atlasów sztucznych; z reguły nie miały tekstu na odwrocie.

\footnotetext{
${ }^{69}$ P. van der Krogt, Koeman's, s. 471 i 598; M. Stelmach, Pomorze, s. 27; R. Skrycki, w: Historia kartografii ziem polskich, s. 293; G. Loeck, Das Kartenbild, s. 133; R. Skrycki, Wielka mapa, s. 135.

${ }^{70}$ P. van der Krogt, Koeman's, S. 37-38; M. Stelmach, Historia kartografii Pomorza, s. 106; por. także G. Loeck, Das Kartenbild, s. 133, gdzie jednak mylnie podano czas przejścia płyt do Schenka i Valka.

${ }^{71}$ M. Stelmach, Historia kartografii Pomorza, s. 106; M. Dworsatchek, Polska, s. 99.

72 P. van der Krogt, Koeman's, s. 123, 598

${ }^{73}$ Tamże, s. 123
} 


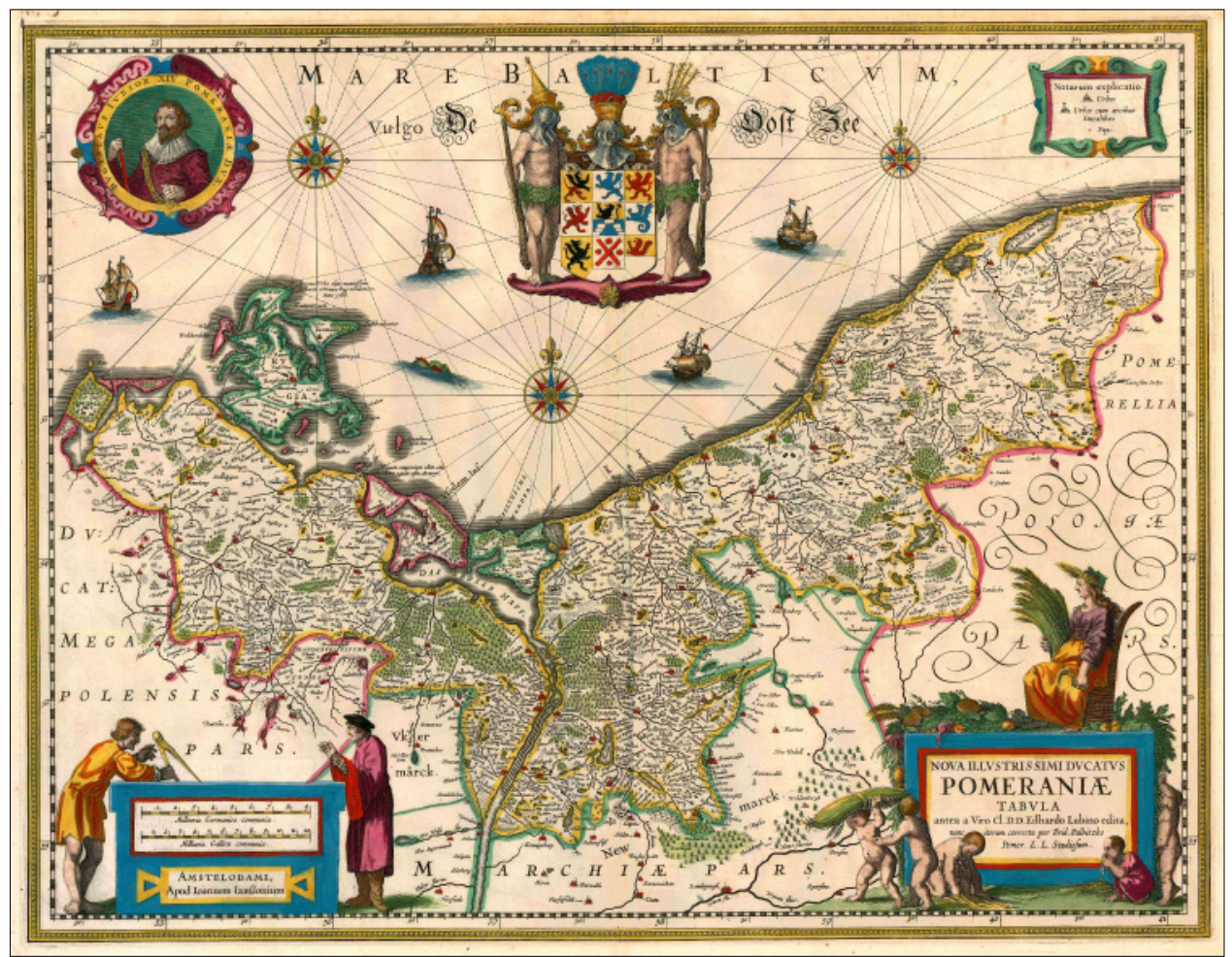

Ryc. 1. Mapa Pomorza Fryderyka Pałubickiego.

Żródto: Antiquariaat SANDERUS, Gandawa

Opis Pomorza drukowany przez oficynę Janssoniusa na odwrocie mapy Pałubickiego $^{74}$ różni się od tego, który Lubinus zamieścił w siedmiu kolumnach u dołu swej wielkiej mapy. Z pewnością nie jest autorstwa Pałubickiego. Dotyczy prawie wyłącznie Pomorza Przedniego (autor przeróbki był związany z Tylnym, o którym w opisie mowa wyłącznie w jednym zdaniu, zawierającym poważne błędy). W całym opisie nie ma w ogóle mowy o Słupsku. Poza tym tekst zawiera informację o zniszczeniu Winety przez króla Konrada, odpowiadającą treścią wcześniejszym mapom, a nie mapie Pałubickiego,

\footnotetext{
${ }^{74}$ Analizowatem tekst z wydania angielskiego z $1636 \mathrm{r}$. (Mercator - Hondius - Janssonius Atlas, s. 131-132), który był przekładem z języka francuskiego. Niestety nie udało mi się dotrzeć do pierwotnego tekstu z 1633 r. C. Schuchhardt, Vineta, s. 206, zwracał uwagę, że badany przez niego tekst z 1633 r. różnit się od późniejszego (z 1649 r.) i nie wspominał 0 Winecie.
}

na której została poprawiona ${ }^{75}$. W ogóle treść opisu odbiega od treści mapy, czego przykładem jest choćby uznanie Rowokołu za miasto, choć Pałubicki dodał ten obiekt do mapy, opisując go jako górę. Przede wszystkim jednak, tekst zamieszczany w atlasach Janssoniusa dość wiernie odpowiada opisowi Pomorza drukowanemu przez oficynę Blaeua na odwrocie pomniejszonej mapy Lubinusa i prawdopodobnie został zaczerpnięty $\mathrm{z}$ atlasów tego ostatniego.

\section{Zmiany wprowadzone w ramach przeróbki, źródła kartograficzne Pałubickiego}

Poniżej przedstawiam najważniejsze zmiany wprowadzone w ramach przeróbki Pałubickiego do zredukowanej mapy

\footnotetext{
7 Na tej podstawie C. Schuchhardt, Vineta, s. 206, uznat, że mapa powstała na Pomorzu, a tekst w Niderlandach.
} 
Lubinusa drukowanej przez Blaeua (zwanej dalej także mapą wyjściowa $)^{76}$.

a) Znacząco zmieniono liternictwo użyte do oznaczenia Meklemburgii i Brandenburgii, a nieco - do oznaczenia Polski. Uwolniło to sporo miejsca na nową treść poza granicami księstwa. Na mapie wyjściowej praktycznie cały teren poza tymi granicami pokryty był zawijasami liter $\mathrm{z}$ napisów oznaczających sąsiadujące kraje.

b) Częściowo naniesiono na mapę sytuację poza granicami księstwa, zwłaszcza w zakresie obszarów położonych w Nowej Marchii (okolice Gorzowa, Kalisza Pomorskiego, Drezdenka) oraz nadodrzańskich terenów Marchii Wkrzańskiej. Między innymi dorysowano i opisano częściowy bieg Warty, Noteci, Drawy, Myśli, Olszy (Welse) oraz trzydzieści miejscowości (siedem po zachodniej i 23 po wschodniej stronie Odry) - żadna z dopisanych nazw rzek i miejscowości nie występuje na wielkiej mapie Lubinusa. Zmiany dotyczące Polski są minimalne: dopisano trzy miejscowości: Wałcz (Krone), Mirosławiec (Fridelandt) i gniazdo Pałubickich, Pałubice w gm. Sierakowice (Palbitz) - dwie pierwsze były nieobecne na wielkiej mapie. Poza tym dodano oznaczenia geograficzne $P O$ MERELLIA, New marck i Vker marck (niewystępujące na wielkiej mapie).

c) Dopisano nazwy wszystkich ważniejszych rzek na Pomorzu Tylnym (Łeba, Słupia, Wieprza, Rega, Parsęta, Łupawa). Z nich Łeba nie była opisana na wielkiej mapie Lubinusa ani na żadnej innej wcześniejszej mapie. $\mathrm{Na}$ zredukowanej mapie Lubinusa opisane są tylko trzy rzeki: Odra (Odera Fluvius),

\footnotetext{
${ }^{76} \mathrm{Na}$ ten temat por. C. Drolshagen, Neuvorpommern, s. 210-212; Katalog, s. 65; M. Stelmach, Historia kartografii Pomorza, s. 102; tenże, Pomorze, s. 26-27; G. Loeck, Das Kartenbild, s. 133; R. Skrycki, w: Historia kartografii ziem polskich, s. 293; tenże, Wielka mapa, s. 135; Noty katalogowe, s. 42. Wszystkie te publikacje podają informacje o zmianach w sposób niewyczerpujący, niekiedy pobieżny.
}

Wkra (Vker fluuius) i Rędowa (Randow flu. $)^{77}$.

d) Pominięto napis Odera Fluvius, skutkiem czego najważniejsza rzeka na mapie została bez nazwy.

e) Dopisano nazwy wysp: Wolin (WOLLINSCHE WERDER.), Uznam (USEDOM Ins.) i Chycina (Hiddensche) oraz cieśnin (lub wejść do cieśnin): Piana (Pene flu. - wbrew brzmieniu hasło to oznacza cieśninę, sama rzeka Piana nie jest opisana na mapie), Świnoujście (Swine ostium; jako obiekt hydrograficzny, nie punkt osadniczy) oraz Dziwnoujście (Divenow Portus - na wielkiej mapie oznaczone jako Portus Dwinov; zmieniono pisownię na poprawniejsza). Z tych nazw Uznam, Piana i Świnoujście nie występują na wielkiej mapie.

f) Dodano niewielką liczbę miejscowości w samych granicach Księstwa Pomorskiego: Ustkę (Stolpmunda), Bukowo Morskie (Buckow; znak punktowy z krzyżem oznaczający miejsce o charakterze sakralnym) oraz Warblewo w gm. Słupsk (Warbelow) - posiadłość rodziny Fryderyka Pałubickiego (być może miejsce jego urodzenia) ${ }^{78}$ na północny zachód od Słupska (w rzeczywistości wieś ta leży na południowy zachód od Słupska, lecz tam nie dało się jej umieścić, bo na wyjściowej mapie obszar ten zajmują wzgórza). Ta ostatnia modyfikacja została dokonana niezdarnie - dopisano nazwę poniżej słowa Sagaritz (Zagórzyca gm. Damnica), nie zaznaczając punktem samej lokalizacji.

g) Nad rzeką Łupawą, poniżej Smołdzina, przy jej ujściu do jez. Gardno napisano bardzo małymi literami w poprzek

\footnotetext{
${ }^{77}$ Mylne są twierdzenia Mieczysława Stelmacha, że na zredukowanej mapie Lubinusa jest opisanych 26 rzek (M. Stelmach, Historia kartografii Pomorza, s. 98; tenże, Pomorze, s. 25). Odmiennie G. Loeck, Das Kartenbild, s. 132, wskazujący, że rzek jest 26, lecz bez informacji o ich opisaniu.

${ }^{78}$ Najstarszym znanym dokumentem poświadczającym posiadanie części Warblewa przez Pałubickich (Jerzego I) jest matrykuła łanowa z $1628 \mathrm{r}$. Matrikeln und Verzeichnisse der Pommerschen Ritterschaft vom XIV bis in das XX Jahrhundert, Hrsg. R. Klempin, G. Kratz, Berlin 1863, s. 269.
} 
rzeki Reuecol mons (góra Rowokół) bez znaku punktowego.

h) Poniżej wzgórz leżących między Koszalinem a Sianowem napisano Gollenberg (Góra Chełmska).

i) W granicach Księstwa Pomorskiego w jednym przypadku zmieniono pisownię miejscowości: z Woße na Wossen (wieś na jednej z wysepek nieopodal Rugii), przy czym nastąpiło to w sposób niezgrabny: znak punktowy podzielił wpisane słowo na dwa. Rozwinięto też jeden skrót: Aderbor. do Aderborgh (Oderberg, bezpośrednio na północ od Szczecina).

j) Dopisano w odpowiednich miejscach dwa erudycyjne komentarze - o pochłonięciu przez morze Winety oraz o zniszczeniu Arkony przez króla duńskiego Waldemara (z tym wiąże się także dodanie odpowiednich znaków oznaczających te dwa miejsca - przy czym, konsekwentnie, Wineta znajduje się na morzu).

k) Zmieniono tytuł mapy (z POMERANIAE DVCATVS TABVLA na NOVA ILLVSTRISSIMI DVCATVS POMERANIE TABVLA).

1) W adresie wydawniczym ujęto Janssoniusa (AMSTELODAMI, Apud Ioannem Ianßonium), a w kartuszu tytułowym Pałubickiego, jako „poprawiającego" mapę. Znikła sygnatura Salomona Rogiersa.

m) Kartusz z herbami Księstwa Pomorskiego zastąpiono zupełnie innym o tej samej tematyce, przy czym jedno z pól (herb Wołogoszczy) jest niekompletne ${ }^{79}$.

n) Dodano kartusz z portretem Bogusława XIV.

o) Wyróżniono graficznie miasta posiadające zamki książęce ${ }^{80}$ i dodano kartusz wyjaśniający to zróżnicowanie (legendę).

\footnotetext{
${ }^{79}$ C. Drolshagen, Neuvorpommern, s. 210; M. Stelmach, Historia kartografii Pomorza, s. 102; tenże, Pomorze, s. 27.

${ }^{80}$ M. Stelmach, Historia kartografii Pomorza, s. 102, mylnie rozumiał, że chodzi tu o miasta książęce, podczas gdy legenda Urbes cum arcibus Ducalibus jest jednoznaczna. Tak więc np. Sławna (miasta książęcego) nie oznaczono tym symbolem, gdyż nie było w nim zamku.
}

p) Zagęszczono okręty na morzu oraz zmieniono i przemieszczono potwora morskiego. Liczbę róż wiatrów zwiększono z dwóch do trzech.

q) Zmieniono napis MARE BALTICVM / Oost Zee na MARE BALITCVM / Vulgo De Oost Zee i zmodyfikowano jego typografię oraz ornamentację.

r) Zastosowano inną siatkę kartograficzną (kwestia ta nie jest omawiana w niniejszej pracy $)^{81}$.

Wśród fragmentów tekstu dopisanych do mapy (nazwy geograficzne i notki historyczne) jest stosunkowo wiele łacińskich, a mało niemieckich, w porównaniu do proporcji pomiędzy tymi językami, które istnieją na mapie wyjściowej.

Nie da się dziś całkowicie jednoznaczne odróżnić zmian wprowadzonych przez Pałubickiego od tych, które są dziełem rytownika. Nie ulega wątpliwości, że od tego ostatniego pochodzą istotne zmiany w typografii, aranżacji graficznej (róż wiatrów, okrętów itp.). Zapewne także tam, gdzie doszło do prostego przeniesienia treści kartograficznej z mapy Visschera dotyczącej większego obszaru na południe od granic Księstwa Pomorskiego, dokonał tego rytownik, choć moim zdaniem $\mathrm{z}$ inicjatywy i według instrukcji Pałubickiego $^{82}$. Inne zmiany merytoryczne przypisuję bezpośrednio słupszczaninowi. To samo dotyczy zmiany tytułu, pomysłu kartusza z portretem księcia oraz nowego kartusza herbowego, do których przygotowania ikonografię musiał dostarczyć osobiście autor przeróbki.

Poza oczywistym podkładem, jakim była pomniejszona mapa Lubinusa, można wskazać inne źródła Pałubickiego. Niewątpliwie posługiwał się wielką mapa Lubinusa ${ }^{83}$ (z 57 dodanych nazw

\footnotetext{
${ }^{81}$ C. Drolshagen, Neuvorpommern, s. 210; M. Stelmach, Historia kartografii Pomorza, s. 100-102 i 123-124; Katalog, s. 65.

82 Por. jednak Katalog, s. 65, gdzie przypisano Pałubickiemu samodzielne naniesienie na mapę sytuacji na południe od granicy księstwa.

${ }^{83} 0$ tym, że miał on w Niderlandach dostęp do odbitek z płyt wielkiej mapy Lubinusa pisał W. Hartnack, Die Küste, s. 15.
} 
geograficznych osiemnaście występuje już na niej i jest pewne, że to z tego źródła zostały zaczerpnięte). Za posłużeniem się wielką mapą przemawiają także wstawki historyczne o Arkonie i Winecie, które autor przeróbki zredagował samodzielnie, ale ich pomysł musiał zaczerpnąć właśnie z niej (albo bezpośrednio z map, z których pomysł ten wziął Lubinus; omawiam je w kolejnym rozdziale). Oczywiście format atlasowy ze swej natury ma ograniczoną pojemność i Pałubicki, wzbogacając mape wyjściową, jedynie w minimalnym stopniu wykorzystał ogromny zasób wiedzy kartograficznej zgromadzonej w wielkim dziele Lubinusa.

Źródłem Pałubickiego, czego dotąd nie zauważono, była także mapa Brandenburgii, Meklemburgii i części Pomorza (TABULA ELECTORATUS BRANDENBURGICI, MECKELENBURGICI, ET MAXIMA PARTIS POMERANIAE) autorstwa Claesa Janszoona Visschera (Nicolausa Piscatora) opracowana w 1629 r., a wzorowana m.in. na mapie Eliasa Camerariusa ( $M A R C A$ BRANDENBVRGENSIS \& POMERA$N I A)$, a także wielkiej mapie Lubinusa ${ }^{84}$. To od Visschera Pałubicki zaczerpnął całą praktycznie treść swej mapy dotyczącą Nowej Marchii i Marchii Wkrzańskiej (z nazwami oznaczającymi te krainy), a także położone w Rzeczypospolitej Wałcz i Mirosławiec wraz nazwą POMERELLIA, którą poprawił z POMERELLA. Ta ostatnia zmiana świadczy o znajomości geografii pomorskiej. Błędną pisownię Visschera (POMERELLA) skopiowano później np. na wydanej po raz pierwszy w 1633 r. innej mapie z atlasów Janssoniusa (BRANDEBVRGVM MARCHIONATUS, cum Ducalibus POMERANIAE ET MEKE$L E N B V R G 1)^{85}$. Z 39 nowych nazw geograficznych, których Pałubicki nie mógł

${ }^{84}$ Omawia ją R. Skrycki, Dzieje kartografii Nowej Marchii do końca XVIII wieku, Warszawa 2008, s. 60-61; tenże, w: Historia kartografii ziem polskich, s. 304.

${ }^{85} 0$ tej mapie: P. van der Krogt, Koeman's, s. 597; R. Skrycki, Dzieje kartografii, s. 63. zapożyczyć z wielkiej mapy Lubinusa, aż 35 występuje na mapie Visschera.

$\mathrm{Na}$ obu mapach Lubinusa (wielkiej i pomniejszonej) brak jest granicy brandenbursko-polskiej, dlatego starostwo drahimskie zaznaczono jako obwiedziony granicami obszar przylegający do Księstwa Pomorskiego, a jego sytuacja w kontekście Brandenburgii i Polski pozostaje nieznana. Dopiero na mapie Visschera zaznaczono, że starostwo to stanowiło klin wbity pomiędzy Nową Marchię i Pomorze, najkrótszym bokiem przystający do Polski. Pałubicki przejął to trafne ujęcie.

Dwie kolejne nowe nazwy (Uznam i Świnoujście) autor przeróbki zaczerpnął z mapy Petrusa Artopaeusa w wersji wydawanej przez Abrahama Orteliusa (POMERANIAE. WANDALICAE REGIONIS TYP.). Nazwy te występują także na mapie Camerariusa, lecz w znacząco innej pisowni niż użyta przez Artopaeusa i Pałubickiego, więc nie zostały z niej zaczerpnięte. Kolejną nazwę (Piana) przejął Pałubicki właśnie od Camerariusa (umieścił ją jak ten ostatni w cieśninie, a nie przy rzece, jak Artopaeus). Ostatnią z nowych nazw, rzekę Łebę, Pałubicki dopisał samodzielnie; wcześniej na mapach nie występowała.

W sumie słupszczanin, nanosząc zmiany na atlasową mapę Lubinusa, korzystał $\mathrm{z}$ aż czterech źródeł pomocniczych, przy czym z wielkiej mapy Lubinusa zaczerpną ok. jednej trzeciej nowych nazw geograficznych.

Tam, gdzie autor przeróbki ingerował w treść kartograficzną w ramach granic księstwa, nadpisywał istniejącą mapę. Stąd obfitość nazw wychodzących na Morze Bałtyckie (w sumie piętnaście pomiędzy Uznamem a granicą polską w porównaniu do siedmiu na mapie wyjściowej). Łatwiej było mu umieszczać nowy tekst na morzu, gdyż ląd był już ciasno zapisany - omówiony powyżej przypadek niezdarnego dopisania Warblewa wskazuje na trudności z wciśnięciem go między zaznaczone już wsie. 
Przyjęcie takiego trybu pracy przesądziło, że w granicach Księstwa Pomorskiego mapa nie zawiera zasadniczych modyfikacji mogących wpłynąć na ocenę jej dokładności (błędy w odległościach pomiędzy miejscowościami), prawidłowości zorientowania itp. $Z$ definicji praca Pałubickiego ma więc, co do terytorium samego Pomorza Zachodniego, wszelkie wady (i zalety) wzoru, na którym pracowat ${ }^{86}$. Dlatego ocenianie jego mapy jako samodzielnego dzieła w tym zakresie mija się $\mathrm{z}$ celem ${ }^{87}$. Zredukowana mapa Lubinusa była oparta na wielkiej, ta zaś na szeroko zakrojonych pomiarach terenowych, których Pałubicki oczywiście nie mógł powtórzyć. Do treści „pomorskiej” mógł jedynie dodać drobne ulepszenia w oparciu o wielką mapę, inne źródła kartograficzne oraz własną orientację. Więcej zmian wprowadził na obszarach poza Księstwem Pomorskim.

\section{Wineta i Arkona}

Ciekawymi elementami odróżniającymi mapę Pałubickiego od zredukowanej mapy Lubinusa są komentarze o Winecie i Arkonie ${ }^{88}$.

Od średniowiecza funkcjonowały mity o bogatym mieście znajdującym się gdzieś u ujścia Odry. Pierwszy przekazał je Ibrahim ibn Jakub około 965 r. piszący o mieście Weltaba, a następnie Adam z Bremy w XI w. Zasadnicza legenda Winety zaczęła tworzyć się w XII w. za sprawą Helmolda z Bozowa, który stworzył nazwę miejscowości funkcjonującą do dzisiaj ${ }^{89}$. Mit

\footnotetext{
${ }^{86}$ Natomiast, ponieważ dokonana przez niego modyfikacja siatki kartograficznej nastąpiła przy niezmienionym nakreśleniu granic księstwa oraz znajdujących się w nim miejscowości, ich wspótrzędne istotnie ulegty pewnej zmianie.

${ }^{87}$ Oceny takiej dokonał C. Drolshagen, Neuvorpommern, s. 210-212, komentując np. orientację mapy.

${ }^{88}$ M. Stelmach, Historia kartografii Pomorza, s. 102, twierdzit, że teksty te Pałubicki zaczerpnął z wielkiej mapy Lubinusa, co jest nieprawdziwe względem Winety i nieprecyzyjne w odniesieniu do Arkony.

${ }^{89}$ Omówienie tej kwestii: L. Leciejewicz, w: Stownik starożytności słowiańskich, red. W. Kowalenko i in., Wrocław-Warszawa-Kraków 1961-1996, t. 6, s. 472. Aktualny stan badań referuje J.M. Piskorski, Pomorze plemienne. Historia, archeologia, językoznawstwo, Wodzisław Śląski 2014, s. 90-91. WXVI w. Winetą interesowat się szczególnie Thomas Kantzow (Pomerania. Eine pommersche Chronik aus dem sechzehnten Jahrhundert, Bd. 1, Stettin 1908, s. 9, 51, 58-60).
}

ten żył przynajmniej do końca XVIII w. Niektóre jego wersje mówią o oblężeniu, zdobyciu lub zniszczeniu Winety przez jakiegoś duńskiego króla, inne o pochłonięciu miasta przez morze.

Winetę lokalizowano m.in.:

a) nieco na północ od Kosarzowa (Koserow, na wyspie Uznam);

b) na wschód od wyspy Ruda (Ruden, na północ od wyspy Uznam);

c) obok Barda (Barth, zdecydowanie na zachód od Rugii).

Dziś powszechnie przyjmuje się, że Wineta, Weltaba, Jomsborg itp. to Wolin albo byty zainspirowane Wolinem ${ }^{90}$. Chodzi o miejscowość na południowym wschodzie wyspy o tej samej nazwie, ośrodek bardzo bogaty we wczesnym średniowieczu, który potem podupadł. Legendy te maja być odbiciem dawnej potęgi Wolina, potwierdzonej przez badania archeologiczne.

Wineta była umieszczana na drukowanych mapach już od połowy XVI w. ${ }^{91}$ :

a) na mapie Pomorza Petrusa Artopaeusa, wydanej przez Sebastiana Münstera (drzeworyt) w 1552 r., potem przez Abrahama Orteliusa od 1573 r., a później przez Cornelisa de Jode - jako okrąła, owalna lub nieregularna (zależnie od wydania), wysepka położona na północ od środkowej lub środkowo-wschodniej części wyspy Uznam;

b) na mapie Orteliusa RVGIAE, USEDOMIAE ET IVLINAE Wandalicarum insularum vera descriptio z 1584 r., w formie sześciu kropek na Bałtyku, na północ od okolic Kosarzowa;

c) w formie i o lokalizacji jak u Artopaeusa, na mapie Eliasa Camerariusa

\footnotetext{
${ }^{90}$ Nadal podejmowane są próby wskazania innych niż Wolin identyfikacji Winety, ostatnio K. Goldman, G. Wermusch, Vineta. Die Wiederentdeckung einer Versunkenen Stadt, Bergisch Gladbach 1999. Publikację tę surowo ocenit J.M. Piskorski, Pomorze, s. 90-91.

${ }^{91}$ Szczegótowe (choć oparte na nieaktualnej wiedzy o kartografii pomorskiej) zestawienie umieszczania Winety na nowożytnych mapach przedstawif C. Schuchhardt, Vineta, s. 202-203. W ostatnim czasie omówił to zagadnienie E. Brooke-Hitching, Atlas lądów niebytych. Największe mity, zmyślenia i pomytki kartografów, Poznań 2017, s. 234-237, jednak zrobit to pobieżnie i w sposób bardzo niestaranny, m.in. przypisał autorstwo wzmianki o Winecie na mapie Pałubickiego Hondiusowi (nie wiadomo któremu).
} 
publikowanej od 1585 r. przez Gerarda Mercatora, tym razem po raz pierwszy z opisem: Wineta emporium destructum Anno 1030 a Conrado rege Danie;

d) na wielkiej mapie Lubinusa (1618 r.) na północny-zachód od Kosarzowa w formie owalnej wysepki (pokrytej cieniowaniem, co miało oznaczać jej zanurzenie) z opisem: Wineta urbs hic quendam desctructa á Conrado Rege Danice (wyspa jest nieobecna na pomniejszonej mapie Lubinusa);

e) na mapie Fryderyka Pałubickiego (1632 r.), po raz pierwszy w innym miejscu: na wschód od Rudy, a na północ od najbardziej wysuniętego na zachód fragmentu Uznamu, w formie regularnego kółeczka z opisem: Wineta emporium olim celeberr. aquar. astu absorbt:

f) na kolejnych mapach Pomorza (Matthäus Merian - 1638 r., Nicolaas Visscher - 1660 r., Frederik de Wit 1688 r., Theodor Danckerts - 1696 r., Johann Baptist Homann - 1716 r., Christoph Weigel - 1718 r., Matthäus Seutter - 1733 r. i in.) oraz Rugii (np. mapa Lubinusa w wersjach Janssoniusa - 1641 r. i de Wita - ok. 1685 r.), w identycznej formie, miejscu i z takim samym łacińskim opisem jak $\mathrm{u}$ Pałubickiego, czasem $\mathrm{z}$ rozwiniętymi skrótami (wyjątkowo bez łacińskiego opisu na mapie Pomorza Nicolasa Sansona d'Abbevile z 1654 r. i kilku późniejszych).

Jak widać, Winetę, ląd nieistniejący (co było oczywiste dla wszystkich znających choćby pobieżnie geografię Pomorza), konsekwentnie lokowano na mapach od początku nowożytnej kartografii, z reguły jako wyspę mającą realne kształty. Jedyną szczegółową mapą, która tego lądu w ogóle nie wskazywała, była pomniejszona mapa Lubinusa. Przerabiając tę ostatnią, Pałubicki dopisał do niej Winetę, przy czym był pierwszym, który wyraźnie napisał na mapie, że miasto zostało pochłonięte przez morze oraz przesuną ja zdecydowanie na zachód, w okolice Rudy. Te innowacje okazały się trwałe. $\mathrm{Na}$ prawie wszystkich późniejszych mapach Pomorza aż do dziewiątej dekady XVIII w. (na mapach Rugii krócej) przejmowano jego sposób prezentacji, lokalizację i opis losu Winety. Badaczem, który szczególnie podkreślał doniosłość przemieszczenia Winety przez autora omawianej przeróbki, był Carl Schuchhardt (zwolennik teorii o położeniu Winety przy Rudzie, stąd jego wysoka ocena Pałubickiego). Zastanawiał się on, czy „uczony pomorski” zaczerpnął wiedzę o prawidłowej (jego zdaniem) lokalizacji Winety z Adama z Bremy, czy też z tradycji ludowej ${ }^{92}$.

Zmianie charakteru Winety z rzeczywistej wyspy na historyczną informację o lądzie już nieistniejącym służył komentarz wyjaśniający przyczyny zniknięcia miasta. Zastąpił on wcześniejsze objaśnienie Camerariusa (użyte też na wielkiej mapie Lubinusa) o zniszczeniu miasta przez króla duńskiego Konrada w 1030 r. Notabene Dania nigdy nie miała takiego króla. Mapa Pałubickiego nie zawiera więc geograficznej nieprawdy (inaczej niż większość jej poprzedniczek) ani oczywistego historycznego błędu, a jedynie podaje informację o starożytniczej ciekawostce (w której prawdziwość w owym czasie nie wątpiono). Pałubickiemu udało się nie utracić romantyczno-historycznego „faktu” (którego zabrakło na zredukowanej mapie Lubinusa), a jednocześnie pogodzić jego prezentację z geograficzną wiernością mapy. Tym należy tłumaczyć trwałość jego ujęcia.

Przemieszczenie Winety na zachód także było uzasadnione. Odzwierciedlało ono fakt, że na początku XIV w. morze podobno pochłonęło spory obszar lądu, z którego pozostała tylko Ruda ${ }^{93}$. W czasach Pałubickiego właśnie tam poszukiwano zaginionego miasta najintensywniej.

\footnotetext{
92 C. Schuchhardt, Vineta, s. 203-206.

${ }^{93}$ Tamże, Vineta, S. 206; K. Goldman, G. Wermusch, Vineta, s. 124-125.
} 
Drugi z dopisków na mapie dotyczy Arkony, najważniejszego grodu plemienia Ranów, położonego na cyplu w północnej części Rugii. W 1168 r. został on zdobyty i w zasadniczej części zniszczony przez króla duńskiego Waldemara $\mathrm{I}^{94}$.

Arkona pojawiła się po raz pierwszy na mapie Orteliusa RVGIAE, USEDOMIAE ET IVLINAE Wandalicarum insularum vera descriptio z $1584 \mathrm{r}$. bez znaku punktowego z prostym opisem $A R C O$ $N A$. Następnie umieszczono ją na mapie Rugii Lubinusa (ok. 1607 r.) jako punkt $\mathrm{z}$ adnotacja Arcona arx et urbs olim munitißima populosißima. Prawie identycznie oznaczono ją na wielkiej mapie Lubinusa (1618 r.), gdzie poprawiono błąd i napisano populosißimaq[ue]. Arkony brak na pomniejszonej mapie Lubinusa (1629 r.). Na mapie Pałubickiego oznaczona została jako punkt z opisem: Arcona Vrbs olim munitißima destructa a Danice Reg. Woldemaro Anno 1168. Wprowadzone zmiany polegały na usunięciu zbędnych powtórzeń: Vrbs zamiast arx et urbs oraz munitißima zamiast munitißima populosißimaq[ue] oraz rozbudowaniu opisu o informację (prawdziwa) o zniszczeniu grodu przez Waldemara w 1168 r. Zmodyfikowana wzmianka nie zajmuje więcej miejsca, jest jednak bogatsza w treść. Na kolejnych mapach Pomorza (Meriana, Visschera, de Wita, Danckertsa, Homanna, Weigla, Seuttera i in.) jest ona ujęta w identycznej formie i z takim samym łacińskim opisem jak u Pałubickiego.

Zarówno obie dodane wzmianki, jak i lokalizacja Winety potwierdzają, że Pałubicki był dobrze obeznany w dziejach ojczystych i aktualnym stanie wiedzy starożytniczej. Zmiany, które wprowadził, zmierzały do eliminacji oczywistego błędu (wzmianka o Konradzie przy Winecie) i wprowadzenia nowych, prawdziwych danych (wzmianka o Waldemarze przy

${ }^{94}$ Szczegótowe informacje podaje W. Łosiński, w: Słownik starożytności stowiańskich, t. 7, s. 372-374.
Arkonie). Zmodyfikowana lokalizacja Winety odpowiadała poglądom z jego czasów.

\section{Rzeczywisty cel sporządzenia mapy}

Kilka charakterystycznych zmian wprowadzonych (moim zdaniem przez Pałubickiego) do pomniejszonej mapy Lubinusa podkreśla szczególny stosunek autora mapy do Bogusława XIV, jego rodu i księstwa.

Po pierwsze, Pałubicki zmienił tytuł mapy (z POMERANIAE DVCATVS TABVLA na NOVA ILLVSTRISSIMI DVCATVS POMERANIE TABVLA). Zdaniem Radosława Skryckiego celem było nawiązanie do wielkiej mapy Lubinusa (NOVA ILLUSTRISSIMI PRINCIPATUS POMERANIE DESCRIPTIO) ${ }^{95}$. Nie musi to być jedyne ani wyczerpujące wyjaśnienie. Podkreślenie szczególnego statusu Księstwa Pomorskiego słowem illustrissimus było u Lubinusa uzasadnione wdzięcznością wobec hojnego mecenasa, a u Pałubickiego zapewne lojalnością wobec dynastii, której jego ojciec był bliskim współpracownikiem. Pałubicki nie musiał tu nawiązywać do tytułu mapy Lubinusa lub nawiązanie to mogło być tylko jednym $\mathrm{z}$ jego motywów.

Po drugie, dodał piękny kartusz z portretem Bogusława XIV. Znając związki jego rodziny z dynastią Gryfitów, możemy założyć, że ten element graficzny mapy pochodzi od niego, a nie od wydawcy, który zresztą nie miał interesu w takim honorowaniu zagranicznego władcy - co innego, gdyby Bogusław był sponsorem sporządzenia mapy, byłoby to jednak wyraźnie na niej zaznaczone. Janssonius zresztą w ogóle nie miał zwyczaju zamieszczać portretów na drukowanych przez siebie mapach.

Po trzecie, wyróżnił graficznie miasta posiadające zamki książęce i dodał kartusz wyjaśniający to zróżnicowanie (legendę). $\mathrm{Na}$ mapach z tamtej epoki zdarzają się objaśnienia znaków różnicujących rangę lub charakter miejscowości (np. wsie, wsie

${ }^{95}$ R. Skrycki, w: Historia kartografii ziem polskich, s. 293. 
z kościołem, miasta, klasztory, siedziby szlacheckie). Jednak pomysł zaznaczania miast posiadających siedziby (zamki) monarsze jest w pełni oryginalny. Był to dobry sposób zareklamowania dynastii Gryfitów i jej władztwa, bowiem zamków tych było istotnie sporo. Zastosowany znak (symbol miasta, nad którym góruje korona) jest wizualnie atrakcyjny.

Nie ulega mojej wątpliwości, że Jerzy Pałubicki I (ojciec Fryderyka), który w chwili powstania mapy był burmistrzem Słupska, członkiem Rady Stanu i człowiekiem wpływowym, cieszącym się znacznym zaufaniem książęcym ${ }^{96}$, wykorzystał powstanie mapy do wzmocnienia swej pozycji na dworze. Zapewne sprezentował władcy egzemplarz atlasu i zwrócił mu uwagę na opracowaną przez swego syna piękną mapę ojczystych stron, ozdobioną książęcym portretem majestatycznym oraz wykazem rodowych zamków. Żaden z dworzan i polityków pomorskich konkurujących z Pałubickim o względy książęce nie mógł równać się z nim w tak wyrafinowanym pochlebstwie: syn Jerzego, student w obcym kraju, nie zapomina o ojczyźnie i nie szczędzi trudu, by cały świat dowiedział się o „najjaśniejszym” księstwie i jego panu. To była międzynarodowa reklama Pomorza w najlepszym wydaniu. Pałubiccy mieli wszelkie prawa do książęcej wdzięczności i zapewne nie przeliczyli się.

Dokładnie w tym czasie Jerzy Pałubicki uczestniczył w ostrych sporach z drugim burmistrzem Słupska, Konradem Labuhnem, ciesząc się w nich wsparciem Bogusława $\mathrm{XIV}^{97}$, a przed książęcym sądem nadwornym toczył się proces pomiędzy Jerzym Pałubickim a Joachimem Ramelem dotyczący dóbr w Niemicy ${ }^{98}$.

${ }^{96}$ Z. Szultka, Pałubiccy, s. 11-12; R. Schuppius, Stolp, s. 103; K. Ślaski, Przemiany etniczne, s. 178.

${ }^{97}$ Z. Szultka, Pałubiccy, s. 12

${ }^{98} 0$ toczonym w 1634 r. procesie z rodziną Ramelów związanym z nabytą od nich Niemicą por. Z. Szultka, Pałubiccy, s. 8. W rzeczywistości spór ten był wieloetapowy i długotrwały - rozpoczą się przynajmniej w 1628 r. (por. Auserlesene Sammlung verschiedener Urkunden und Nachrichten, Welche zur Kenntniß der Landes-Verfassung und Rechte des Herzogthums
Dopiero powyższe okoliczności pozwalają zrozumieć zamysł stojący za powstaniem mapy. Nie była to spontaniczna inicjatywa studenta, który postanowił poprawić niedoskonałą mapę rodzinnych stron napotkaną $\mathrm{w}$ jednym $\mathrm{z}$ holenderskich atlasów. Mapa została stworzona w zamiarach politycznych (budowa wpływów na dworze książęcym). Jerzy Pałubicki zapewne zachęcał syna do stworzenia mapy i udzielał mu wszelkiej pomocy w najlepiej pojętym interesie obydwu.

\section{Zakończenie}

Fryderyk Pałubicki dodał do zredukowanej mapy Lubinusa przynajmniej 57 nowych nazw geograficznych (3 krainy, 36 miejscowości, 11 rzek, 2 wyspy, 3 cieśniny, 2 góry $)^{99}$, a także dwa obiekty o charakterze starożytniczo-mitologicznym (Winetę i Arkonę). Około 20 proc. obszaru lądowego pokrytego przez mapę (część Marchii Wkrzańskiej i Nowej Marchii oraz okolice Wałcza) otrzymało zupełnie nową treść kartograficzną zaczerpniętą z mapy Visschera. Dlatego w mojej opinii niesłuszne są wyrażane w nauce opinie, że autor przeróbki ingerował w tresś zredukowanej mapy Lubinusa „w bardzo minimalnym stopniu" ${ }^{100}$ albo że „zmiany te trudno zaliczyć do istotnych [...], jest to raczej nowy sztych mapy E. Lubinusa"101. Trafniejsza byłaby opinia, że przeróbka Pałubickiego stanowi udaną kompozycję złożoną z pomniejszonej mapy Lubinusa i części mapy Visschera, uzupełnioną

Vor- und Hinter-Pommern, wie auch des Fürstenthums Rügen, dienen können. Zwente Ausfertigung, Rostock und Wismar 1756, s. 422) i trwał jeszcze, przy udziale Jerzego II i Macieja, w siódmej, a może nawet ósmej dekadzie XVII w. (por. J. Brunneman, Consilia sive Responsa Academica in quibus materiae gravissimae inter Principes pariter ac privatos in foris illustribus ventilatae, Francofurti ad Viadrum 1704, s. 447-449). Zapewne tego sporu dotyczy prośba Macieja Pałubickiego skierowana (prawdopodobnie w ostatnim okresie jego życia - zmart w 1677 r.) do króla Szwecji Karola XI, by interweniował u elektora brandenburskiego w sprawie ojcowizny Macieja położonej na Pomorzu Tylnym (por. W. Nisser, Mathias Pabitzki, s. 28).

${ }^{99}$ Niektóre z tych nazw mógł przerysować z mapy Visschera sam rytownik, ale, jak wskazywałem powyżej, w mojej opinii według instrukcji Pałubickiego. ${ }^{100}$ R. Skrycki, Wielka mapa, s. 135.

${ }^{101}$ M. Stelmach, Historia kartografii Pomorza, s. 102. 
dodatkowymi informacjami zaczerpniętymi z wielkiej mapy Lubinusa, przynajmniej dwóch innych map oraz pewnym wkładem własnym autora.

Mapa Pałubickiego ma wysokie walory estetyczne. O jej artystycznej przewadze nad mapą wyjściową przesądzają nowe kartusze, lepsza kompozycja, brak dziwacznych zawijasów pokrywających sąsiednie krainy, ciekawe symbole użyte do zaznaczenia miast z zamkami.

Największą zaletą tej mapy jest naniesienie sytuacji geograficznej poza granicami Księstwa. Niewiele mniejszą - opisanie wysp i rzek, bezimiennych na mapie wyjściowej. Ciekawe notki erudycyjne dodatkowo zwiększają atrakcyjność mapy. Z powyższych względów to mapa Pałubickiego, bardziej niż zredukowana mapa Lubinusa $\mathrm{z}$ atlasów Blaeua, była punktem odniesienia dla kolejnych dzieł kartografii atlasowej. Bezpośrednio wywarła pewien wpływ przynajmniej na mapy Meriana z 1638 r., Sansona d'Abbevile z 1654 r. oraz Visschera z 1660 r., a za pośrednictwem dwóch ostatnich oddziaływała (w pewnym zakresie) na kartografię Pomorza Zachodniego do XVIII w. ${ }^{102}$ Przez półtora wieku kopiowane były bez żadnych zmian pochodzące od $\mathrm{Pa}$ łubickiego komentarze dotyczące Arkony i Winety oraz umiejscowienie tej ostatniej.

Pałubickiego trudno jednak uznać za kartografa we właściwym znaczeniu tego słowa. Badań terenowych nie prowadził. Znajomości matematyki ani astronomii nigdy nie ujawnił. Nie wniósł od siebie szczególnie istotnych nowych treści kartograficznych. Jego rola miała zasadniczo charakter kompilacyjny, a wkład niezaprzeczalnie własny dotyczył albo spraw drobnych (opisanie - po raz pierwszy w dziejach kartografii - rzeki Łeby, wskazanie na mapie miast posiadających zamki książęce, poprawienie błędnych zapisów Dwinow i Pomerella na lepsze Divenow i Pomerellia), albo zagadnień innych niż ściśle kartograficzne (kwestia Arkony i Winety). Nic też nie wiadomo o jakichkolwiek innych dziełach kartograficznych słupszczanina. Dlatego trafniejsze jest nazwanie go kompilatorem.

\section{Bibliografia}

Źródła drukowane i druki współczesne

Album studiosorum Academiae Lugduno Batavae 15751875, Hagae Comitum 1875.

Auserlesene Sammlung verschiedener Urkunden und Nachrichten, Welche zur Kenntniß der Landes-Verfassung und Rechte des Herzogthums Vor- und Hinter-Pommern, wie auch des Fürstenthums Rügen, dienen können. Zwente Ausfertigung, Rostock und Wismar 1756.

Brunneman J., Consilia sive Responsa Academica in quibus materiae gravissimae inter Principes pariter ac privatos in foris illustribus ventilatae, Francofurti ad Viadrum 1704.

Die Matrikel der Universität Rostock, Hrsg. A. Hofmeister, Rostock 1895.

Die Matrikel und die Promotionsverzeichnisse der Albertus-Univesität zu Königsberg i. Pr., B. 1: Die Immatrikulationem von 1544-1656, Hrsg. G. Erler, Leipzig 1916.

Janssonius J., Theatrum Imperii Germanici, Amstelodami 1632.

Kantzow T., Pomerania. Eine pommersche Chronik aus dem sechzehnten Jahrhundert, Bd. 1, Stettin 1908.

Katalog dawnych map Rzeczypospolitej Polskiej w kolekcji Emeryka Hutten Czapskiego, t. 2: Mapy XVII wieku, oprac. T. Paćko, D. Stachnal-Talanda, E. Gołąb-Jankowska, Wrocław-Warszawa-Kraków 1992.

Leuschner M., Disputationum ethicarum I-IX, Stetini 1629.

Matrikeln und Verzeichnisse der Pommerschen Ritterschaft vom XIV bis in das XX Jahrhundert, Hrsg. R. Klempin, G. Kratz, Berlin 1863.

\footnotetext{
${ }_{102}$ Tytułem przykładu, autorzy późniejszych map Pomorza (N. Sanson d'Abbeville, N. Visscher, F. de Wit, T. Danckerts, J.B. Homann i C. Weigel) nieświadomi znaczenia Pałubic umieszczonych na mapie Pałubickiego, przerabiali je na Pardubitz i utożsamiali z odległym $060 \mathrm{~km}$ Puckiem.
} 
Pitt M., Janssonius van Waesbergen J., Swart S., The English Atlas, vol. 2, Oxford 1681.

Pomorze Zachodnie pod rzadami książat plemiennych i wtadców z dynastii Gryfitów (990-1121-16371648/53), wyd. Z. Szultka, Poznań-Gdańsk 2006 (Źródła do kaszubsko-polskich aspektów dziejów Pomorza Zachodniego do roku 1945, 1).

Praetorius J., Blenno A., Palbitzky G, Palbitzky F. i in.,

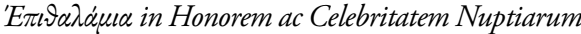

\section{Opracowania}

Alexandrowicz S., Łuczyński J., Skrycki R., Historia kartografii ziem polskich do końca XVIII wieku, Warszawa 2017.

Bartholdy W., „O Stolpa, du bist ehrenreich...” kulturgeschichtliche Beiträge zur Kirchen- und Stadtgeschichte von Stolp, Stolp 1910.

Brooke-Hitching E., Atlas lądów niebytych. Największe mity, zmyślenia i pomytki kartografów, Poznań 2017.

Dopierała B., Polskie losy Pomorza Zachodniego, Poznań 1970.

Drolshagen C., Neuvorpommern und Rügen im Rahmen der älteren Kartographie und Landesaufnahme, „Pommersche Jahrbücher”, 10, 1909, s. 163-216.

Dworsatchek M., Polska $w$ dawnej kartografii. Historyczne ziemie polskie na mapach do poczattku XIX wieku w zbiorach Ossolineum, Wrocław 2008.

Freith J., Kaczmarczyk H., Malczewski I., Żeglarski H., Kronika najważniejszych wydarzeń z dziejów miasta Stupska i powiatu stupskiego, w: Szkice stupskie. Praca zbiorowa, red. A. Benesz i in., Poznań-Słupsk 1960 , s. 44-54.

Hartnack W., Die Küste Hinterpommerns unter besonderer Berücksichtigung der Morphologie, Greifswald 1926.

Historia Pomorza, red. G. Labuda, t. 2: Do roku 1815 , cz. 1: 1464/66-1648/57, oprac. M. Biskup, M. Bogucka, A. Mączak, B. Wachowiak, Poznań 1976.

Historia Pomorza, red. G. Labuda, t. 2: Do roku 1815, cz. 3: Pomorze Zachodnie w latach 1648-1815, oprac. Z. Szultka, H. Lesiński przy współudziale D. Łukaszewicza i A. Wielopolskiego, Poznań 2003.

Historia Stupska, red. S. Gierszewski, Poznań 1981.

Goldman K., Wermusch G., Vineta. Die Wiederentdeckung einer Versunkenen Stadt, Bergisch Gladbach 1999.

Gwiazdowska E., O ikonografii Wielkiej Mapy Księstwa Pomorskiego Eilharda Lubinusa, w: Eilharda Lubinusa podróż przez Pomorze, red. R. Skrycki, Szczecin 2013, s. 165-222.

Kaczmarczyk H., Szkice stupskie (XVI-XVII w.), w: Szkice stupskie. Praca zbiorowa, red. A. Benesz i in., Poznań-Słupsk 1960, s. 5-21.

Koeman C., Atlantes Neerlandici. Bibliography of terrestrial, maritime and celestial atlases and pilot books
Pl. Reverendi, Clarissimi et Doctissimi Viri Dn. M. Petri Zimmermanni Pastoris Ecclesiae Stolpicae, Dantisci 1637, Elektroniczna Baza Bibliografii Estreichera (https://www.estreicher.uj.edu.pl/staropolska/ $\mathrm{baza} /$ wpis/?sort=id\&order $=1$ \&offset $=47129 \& \mathrm{i}$ $\mathrm{d}=163098$ \&index=21, dostęp: 25 lutego 2019).

published in the Netherlands up to 1880, vol. 2: Blussé-Mercator, Amsterdam 1969.

Kratz G., Die Städte der Provinz Pommern, Berlin 1865.

Krogt P. van der, Koeman's Atlantes Neerdladici, New Edition, vol. 1: The Folio Atlases Published by Gerard Mercator, Jodocus Hondius, Henricus Hondius, Johannes Janssonius and Their Successors, 't Goy-Houten 1997.

Lindmajer J., Machura T., Spors J., Wachowiak B., Dzieje Stupska, Słupsk 1986.

Loeck G., Das Kartenbild von Pommern zur Hansezeit, „Baltische Studien. Pommersche Jahrbücher für Landesgeschichte”, 90, 2004, s. 87-134.

Mercator - Hondius - Janssonius Atlas or Geographicke description of the World [reprint], Amsterdam 1968.

Micraelius J., Sechs Bücher vom alten Pommernland, Buch 6: Von deß Pommerlandes Gelegenheit und Einwohnern, Stettin und Leipzig 1723.

Moser J.J., Landeshoheit in Regierungssachen überhaupt, Franckfurt-Leipzig 1772.

Nisser W., Mathias Palbitzki. Som connoisseur och tecknare, Uppsala 1934.

Noty katalogowe, w: Eilharda Lubinusa podróż przez Pomorze, red. R. Skrycki, Szczecin 2013, s. 17-44.

Oerlichs J.C.C., Zuverläßige historisch-geographische Nachrichten vom Herzogthum Pommern und Fürstenthum Rügen, Berlin 1771.

Piskorski J.M., Pomorze plemienne. Historia, archeologia, językoznawstwo, Wodzisław Śląski 2014.

Rembalski T., Patubiccy z Ostawy Dąbrowy, „Pomerania”, 12, 2006, s. 30-35.

Schuchhardt C., Vineta, „Sitzungsberichte der Preussischen Akademie der Wissenschaften. PhilosophischHistorische Klasse”, 1924, s. 176-208.

Schuppius R., Die Familiennamen von Stolp und Umgebung im 16. Jahrhundert. 2. Auflage, [b.m.w.] 1930.

Schuppius R., Stolp von 1600-1650. Friedensarbeit und Kriegsnöte einer pommerschen Stadt, Stolp 1930.

Skrycki R., Dzieje kartografii Nowej Marchii do końca XVIII wieku, Warszawa 2008.

Skrycki R., Wielka mapa Pomorza Eilharda Lubinusa a kartografia regionu, w: Eilharda Lubinusa podróz przez Pomorze, red. R. Skrycki, Szczecin 2013, s. $117-138$. 
Stownik starożytności stowiańskich, red. W. Kowalenko, G. Labuda, T. Lehr-Spławiński, Z. Stieber, Wrocław-Warszawa-Kraków 1961-1996.

Stelmach M., Eilhardus Lubinus i jego wielka mapa Księstwa Pomorskiego, Szczecin 2001.

Stelmach M., Historia kartografii Pomorza Zachodniego do końca XVIII wieku, Szczecin 1991.

Stelmach M., Pomorze i Szczecin na dawnych mapach, planach i widokach. Katalog wystawy, Szczecin 1998.

Szeliga J., Doktadność mapy Pomorza Eilharda Lubinusa, w: Eilharda Lubinusa podróż przez Pomorze, red. R. Skrycki, Szczecin 2013, s. 139-164.

Szultka Z., Patubiccy - burmistrzowie, rajcy i obywatele Stupska końca XVI i pierwszej potowy XVII wieku, „Rocznik Słupski”, 1979, s. 7-27.

Szultka Z., Z badań nad rodowodem i struktura patrycjatu stupskiego w drugiej potowie XVI i w pierwszej potowie XVII wieku, „Zapiski Historyczne”, 47 (2), 1982, s. 33-49.
Szultka Z., Z problematyki stosunków etnicznych Stupska i okolicy w XIV-XVIII wieku, „Rocznik Koszaliński”, 11, 1975, s. 58-76.

Ślaski K., Beiträge zur Geschichte Pommerns und Pommerellens, Dortmund 1987.

Ślaski K., Polskość Pomorza zachodniego w świetle źródet XVI-XVIII w., w: Pomorze nowożytne, red. G. Labuda, S. Hoszowski, Warszawa 1959 (Szkice z dziejów Pomorza, 2), s. 34-74.

Ślaski K., Przemiany etniczne na Pomorzu Zachodnim w rozwoju dziejowym, Poznań 1954.

Wachowiak B., Pankowie w wizytacjach domeny bytowskiej z drugiej potowy XVI wieku, „Acta Cassubiana”, 8, 2006, s. 24-42.

Wendt J.A., Skarby kartografii, Warszawa 2013.

Wustrack C.F., Nachtrag zur Kurzen historisch-geographisch-statistischen Beschreibung von dem königlichpreußischen Herzogtum Vor- und Hinterpommern, Stettin 1795.

\section{Fryderyk Pałubicki, a mayor of Słupsk (Stolp), and his contribution to the creation of a modified variant of the atlas version of Eilhard Lubinus's Pomerania map}

\section{Summary}

A seventeenth-century map of Pomerania, published by the Hondius-Janssonius firm, was a reworking of a similar map published by Blaeu (originally by J. Hondius Jr). The person named on the reworked map as Frid. Palbitzke has now been identified as Fryderyk Pałubicki (Fridericus or Friederich Palbitzki), a member of a Polish-Kashubian noble family settled in the town of Stupsk (Stolp). He was a Landrath and a mayor of Słupsk, and a promoter of a Polish-language school there. It is asserted that he had a fundamental role in preparing the map, which he created in 1631 or 1632, while studying law in Leiden. The aim was political: the map was meant as flattery addressed to Duke Bogislaw XIV of
Pomerania. Pałubicki's father was an influential Pomeranian statesman engaged at that time in bitter political and legal disputes and needed the duke's support (which he received). The innovations introduced by Pałubicki to the Blaeu map are discussed in detail (including dozens of added geographical names) - they had been somewhat underestimated in the scholarship. The actual Pomeranian territory received slight alterations, but the area to the south has been depicted anew, based on Visscher's Brandenburg map. Special attention is paid to the venue and description of the mythical Vineta - Pałubicki's view of this feature lingered in Pomeranian cartography for c. 150 years.

mgr Roch Pałubicki - z zawodu prawnik. Zainteresowania badawcze: historia kartografii, geografia historyczna, historia Pomorza, historia rodziny Pałubickich. Autor monografii pt. Biber-Pałubiccy. Dzieje awansu i germanizacji rodziny pomorskiej od XVIII do XX wieku (rp@upto.pl)

Roch Pałubicki, MA - a lawyer by profession. Research interests: history of cartography, historical geography, history of Pomerania and Pałubicki family history. Author of a monograph The Biber-Pałubickis. A History of Advancement and Germanization of a Pomeranian Family in the 18th-20th centuries (rp@upto.pl) 